\title{
Dinoflagellate cyst stratigraphy of the Miocene Hodde and Gram Formations, Denmark
}

\author{
STEFAN PIASECKI
}

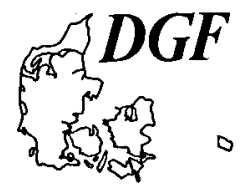

Piasecki, S.: Dinoflagellate cyst stratigraphy of the Miocene Hodde and Gram Formations, Denmark. Bull. geol. Soc., Denmark, vol. 29, pp. 53-76, Copenhagen, June 10th, 1980. https://doi.org/10.37570/bgsd-1980-29-03

\begin{abstract}
A dinoflagellate cyst stratigraphy is proposed for the Hodde and Gram Formations in western Jylland, Denmark. Four biozones are defined and the formations are dated by dinoflagellate cysts to be of Middle and Upper Miocene age, which supports previous dating by molluscs. One new genus and four new species are described: Labyrinthodinium truncatum gen. nov. sp. nov., Dinopterygium verriculum sp. nov., Ap-teodinium tectatum sp. nov. and Nematosphaeropsis aquaeducta sp. nov.

Stefan Piasecki, Institut for Historisk Geologi og Palaontologi, Øster Voldgade 10, DK-1350 København $K$, Danmark, January 18th, 1980.
\end{abstract}

During Miocene time the eastern margin of the North Sea Basin was located in Denmark. A series of transgressions and regressions resulted in a series of interfingering marine and nonmarine deposits several hundred metres thick. Three main transgressions and two main regressions have been recognized giving the basis for a division of the Miocene sediments into six formations (Sorgenfrei, 1940, 1958 and Rasmussen, 1956, 1961).

Sediments from the final Miocene transgression in Denmark were formerly well exposed in many clay and browncoal pits in western Jylland (Rasmussen, 1966), but today, only four localities show well exposed sections, namely, the Gram and Hauge claypits and the browncoal pits near Fasterholt and Ørnhøj (fig. 1). The lower sediments consist of alternating sand and black clay which are overlain by the uniform black, bituminous Hodde clay. These two sedimentological units are united into the Hodde Formation (Rasmussen, 1961). The Gram Formation (Rasmussen, 1961) overlies the Hodde Formation and consists of a basal glauconitic clay succeeded by the brown to grey fossiliferous Gram clay which becomes more silty toward the top. The Hodde clay and the glauconite clay contain no macrofossils, but the Gram clay is very rich in molluscan fossils. Benthonic foraminifera are abundant in both the Hodde and Gram Formations (Kristoffersen, 1972). Planktonic foraminifera have been reported from the Gram clay only (Ersgaard et al, 1977), but have not been worked out in details. A planktonic foraminifera fauna, in sample 5.0-5.5 metres below surface in the Gram boring, consists of very small forms of Globorotalia continuosa Blow, Neogloboquadrina cf. acostaensis (Blow) and very few specimens of Globigerina bulloides d'Orb. and Neogloboquadrina dutetrei - group (Dr. F. Rögl, pers. comm.). This fauna corresponds to the planktonic foraminiferal zones $\mathrm{N} 15$ - N 16, Upper Miocene. The Hodde and Gram Formations are assigned to the Middle and Upper Miocene respectively, mainly on the basis of the molluscan faunas from the lower part of the Hodde Formation (below the Hodde clay) and from the Gram clay. The faunas are comparable with the North German molluscan faunas (Rasmussen, 1966).

The present work establishes a dinoflagellate cyst stratigraphy for these sediments. Samples were collected from measured sections in the pits at Hauge, Fasterholt and Ørnhøj. In addition a number of samples from a boring at Gram made by the Geological Survey of Denmark have been included in this investigation (DGU file 141 423). Samples from this boring are not contaminated with sediments from higher levels, as only the undisturbed core of each sample is used.

Standard palynological preparation techniques were used, and residues were sieved through a 20 $\mu \mathrm{m}$ net and mounted as strew-preparations in Eukitt. The type species are stored in the Geological Museum of the University of Copenhagen (MGUH). 


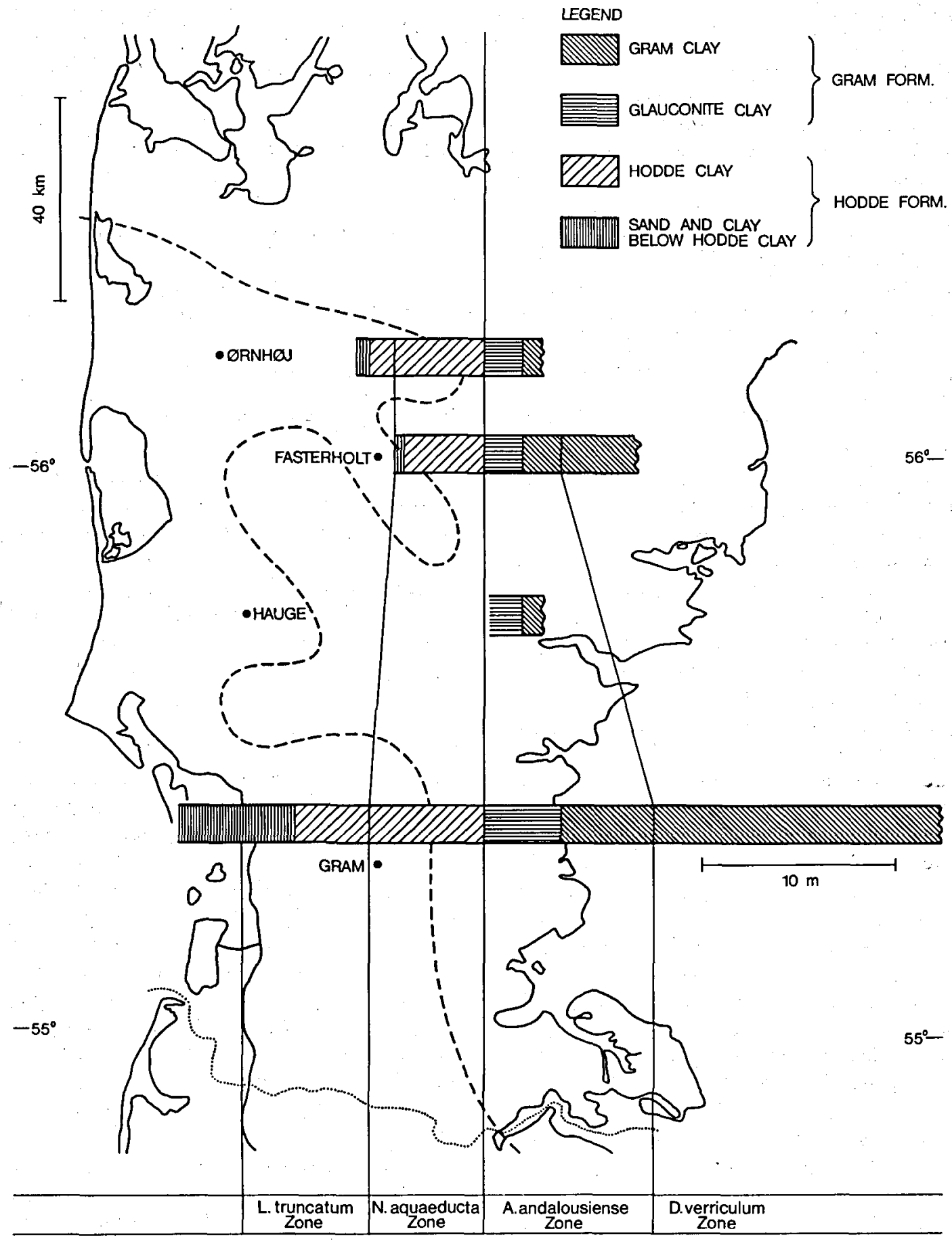

Fig. 1. The distribution of the Hodde and Gram Formations in Jylland (after Rasmussen; 1960) and the positions of the localities, combined with the lithology and biostratigraphy. 


\section{Lithology}

\section{Gram}

The Gram boring is 120 metres deep (fig. 2). The lower 80 metres consist, mainly, of finegrained sand with two clay and silt dominated intervals. Gravel and concretionary horizons occur as minor constituents. Molluscs are recoverable from two intervals and dinoflagellate cysts are found, mainly, in the clay and silts. The sandy sequence is correlated with the Odderup Formation of Rasmussen (1961), which was considered to be deposited under limnic conditions. Approximately 45 metres of this sandy sequence contain marine fossils (fig. 2).

The upper 40 metres of the boring provided clay and silt belonging to the Hodde clay, glauconite clay and Gram clay. The Hodde Formation is defined (Rasmussen, 1961) to include a sequence of alternating black clay and silt or finesand below the Hodde clay. Accordingly, the lower boundary of the formation is often difficult to place accurately. In this work, the lower boundary is considered to be at the base of the first sequence of alternating clay and silt below the Hodde clay in the Gram boring. The upper boundary of the Hodde clay, and the boundary between the glauconite clay and the Gram clay, are precisely determined from the changes in colour, pyrite and glauconite content (Ersgaard et al.; 1977). The positions of the samples examined are shown in fig. 3.

\section{Hauge}

The accessible part of the section in the waterlogged claypit at Hauge consists of 2 metres of glauconite clay and one metre of Gram clay (fig. 3). According to Rasmussen (1966) the thickness of the glauconite clay in this region ranges from 1-2 metres. Therefore, the glauconite clay sequence at Hauge may well be complete, though the lower boundary is not exposed. The upper part of the Gram clay is mixed with Quaternary sediments.

\section{Fasterholt}

The Hodde clay is exposed at several localities in the Søby-Fasterholt region, where browncoal was mined until 1970. The Hodde Formation overlies the limnic Odderup Formation, which in the upper part consists of planar cross-bedded, mica-rich quartz sand, which changes into the basal gravel bed of the Hodde Formation. The Hodde Formation is succeeded by glauconitic clay and Gram clay at one locality in the region, Lavsbjerg. The strata are weakly folded, but little disturbance of the original bedding is apparent. The marine sequence is terminated upward by glacial erosion (fig. 3).

\section{Ørnhøj}

The uppermost part of the Odderup Formation, the Hodde Formation and a part of the Gram Formation are exposed in a slightly dipping sequence in an abandoned browncoal pit at Lille Spåbæk (Rasmussen, 1966) west of the village Ørnhøj. The Odderup Formation consists of planar cross-bedded quartsitic sand with thin laminated beds of silt and clay. The Hodde Formation consists of gravel and black clay, changing into black, bituminous Hodde clay 0.5 metres above the lower boundary. Two metres of glauconitic clay overlie the Hodde clay, and approximately one metre of Gram clay is found below the glacial deposits which terminate the sequence (fig. 3 ).

\section{Biostratigraphy}

Rich and well preserved dinoflagellate cyst assemblages are abundant in the Hodde and Gram Formations of the Gram boring, and accordingly this sequence is used herein as the standard section for the dinoflagellate cyst distribution in both the Hodde and Gram Formations. In addition, preliminary investigations of the dinoflagellate flora in the underlying Odderup Formation indicate the downward ranges of some species at this one locality. No dinoflagellate cysts have been found in the Odderup Formation at Fasterholt and $Ø$ rnhøj. A number of species from the Hodde and Gram Formations are known to occur in older deposits of the North Sea Basin, but have not been recorded in the Odderup Formation during this study. Accordingly their extensions downwards are marked on the rangechart from the Gram sequence with broken lines'only (fig. 4).

Most of the species are found throughout the sequence, but a few have a restricted occurrence. Hemicystodinium zoharyi (Rosignol) Wall, 1967 occurs abundantly in two samples from the lowest 


\section{GRAM BORING}

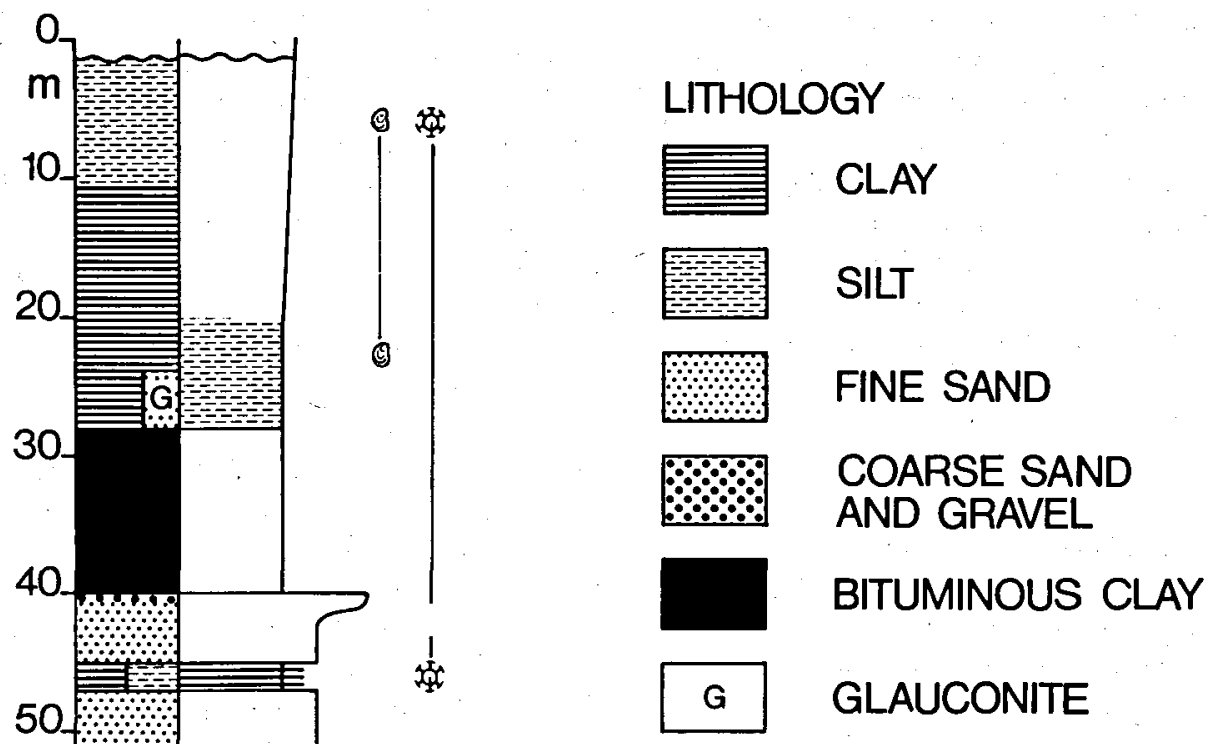

STRUCTURE

C CLAY: UNSTRUCTURED

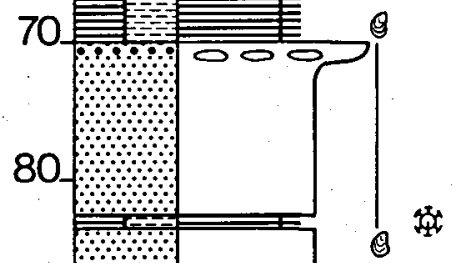

SAND: NO INFORMATION

琶垔園 WEAK LAMINATION

INTERLAMINATED
CLAY AND SILT

PLANAR

CROSS-BEDDING

OO CONCRETIONS

\section{FOSSILS}

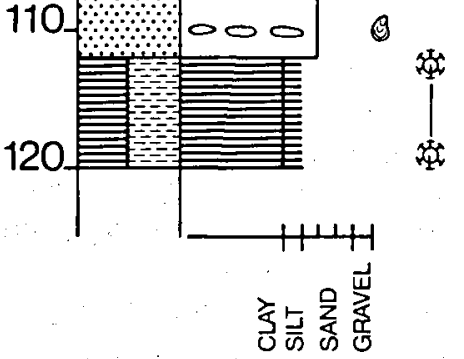

() MOLLUSCS

DINOFLAGELLATE CYSTS

POSITION OF SAMPLES

Fig. 2. Sedimentological section of the Gram boring (modified after Ersgaard et al. 1977). 
part of the Hodde Formation (i.e. below the first zone considered here), but has not been found at any higher level in the sequence. The last occurrence of this species may well be a useful marker horizon in the North Sea sediments, even though the species is the cyst of Pyrodinium bahamense Plate, 1906, which has a Recent distribution that is highly temperature dependent. A number of species occur for the first time in this sequence at $\mathbf{4 1 . 5}$ metres below the surface (fig. 4). The exact first occurrence is to some extent facies dependent, as no dinoflagellate cysts have been found in the sand between $41.5-45.0$ metres.

\section{Labyrinthodinium truncatum Zone nov.}

Definition: Interval from the first occurrence of Labyrinthodinium truncatum gen. nov. sp. nov. to the first occurrence of Nematosphaeropsis aquaeducta sp. nov.

Reference section: Boring at Gram town: DGU file $141423,42.0-36.0$ metres below surface.

Local correlation: The lower 2.5 metres of the Hodde Formation at $\emptyset$ rnhøj is included in this zone.

Stratigraphical range: Middle Miocene below $N$. aquaeducta Zone nov.

Remarks: Tectatodinium pellitum Wall, 1967, Apteodinium tectatum sp. nov., Spiniferites mirabilis (Rossignol) Wall, 1967 and Labyrinthodinium truncatum gen. nov. sp. nov. occur for the first time at the lower boundary of this zone in the Gram sequence. T. pellitum is found throughout the Gram sequence, but $A$. tectatum and $S$. mirabilis are restricted to the $L$. truncatum Zone in the Gram sequence, though they are known to occur higher in the sediments at Fasterhold and Ørnhøj. Distatodinium paradoxum (Brosius) Eaton, 1976 occurs for the last time in this zone and may be stratigraphical useful. It is not believed to be redeposited because it occurs in most of the Lower to Middle Miocene samples from southern Jylland. Tectatodinium psilatum Wall \& Dale, 1973, Spiniferites sp. B. and gen. et sp. indet. occur for the first time in this zone. The dinoflagellate assemblage of this zone and the overlying zone are dominated by Systematophora placacantha (Deflandre \& Cookson) Davey, Downie, Sarjeant \& Williams, 1969. Lingulodinium machaerophorum (Deflandre \& Cookson) Wall, 1967 and Operculodinium cen- trocarpum (Deflandre \& Cookson) Wall, 1967 are also well represented in the assemblage.

Nematosphaeropsis aquaeducta Zone nov. Definition: Sediments containing Nematosphaeropsis aquaeducta sp. nov. Lower boundary at the first occurrence of $N$. aquaeducta and upper boundary at the first occurrence of Achomosphaera andalousiense Chene, 1977.

Reference section: Boring at Gram town: DGU file 141423 , 36.0-29.0 metres below surface.

Local correlation: The zone is found in the Hodde clay, 4 metres thick, at Fasterholt and in the upper 4 metres of the Hodde clay at $\varnothing$ rnhøj. Stratigraphical range: Middle Miocene above Labyrinthodinium truncatum Zones nov. and below Achomosphaera andalousiense Zone nov. Remarks: Achomosphaera alcicornu (Eisenack) Dacey \& Williams, 1966 and gen. et sp. indet. occur for the last time close to the upper boundary of this zone, and the dominating species of the zorle $S$. placacantha occurs for the last time at the upper boundary, together with $L$. truncatum and N. aquaeducta.

Achomosphaera andalousiense Zone nov. Definition: Interval from the first occurrence of Achomosphaera andalousiense Chene, 1977 to the first occurrence of Dinopterygium verriculum sp. nov.

Reference section: Boring at Gram town: DGU file 141 423, 29.0-20.0 metres below the surface. Local correlation: All the exposed sediments of the Gram Formation at Hauge and Ørnhøj (approximately 3 metres) and the lower 4 metres of the Gram Formation at Fasterholt belong to this zone.

Stratigraphical range: Upper Miocene above the Nematosphaeropsis aquaeducta Zone nov. and below the Dinopterygium verriculum Zone nov. Remarks: A. andalousiense is abundant in the Gram sequence from its first occurrence up to 22 metres below the surface, whereas it occurs more sporadically higher in the sequence. The last occurrences of Spiniferites sp. A, Spiniferites sp. B, Cyclopsiella elliptica Drugg \& Loeblich, 1967 and Pentadinium laticinctum Gerlach, 1961 are found in this zone, but apparently the exact positions of these last occurrences vary within the zone at the different localities. 
GRAM BORING

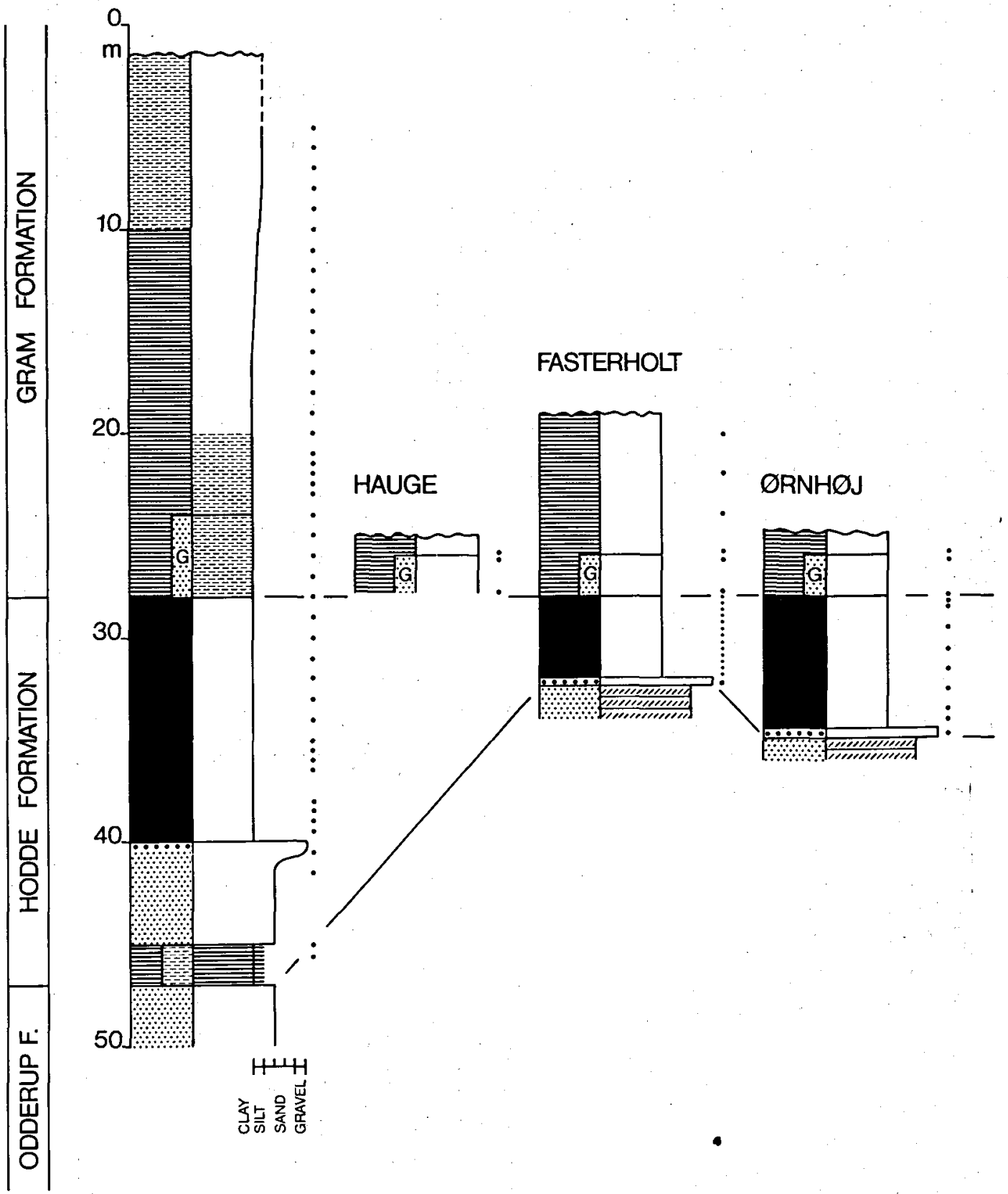

Fig. 3. Sedimentological sections of the Hodde and Gram Formations at Gram, Hauge, Fasterholt and Ørnhøj with the positions of samples. Legend see fig. 2. 


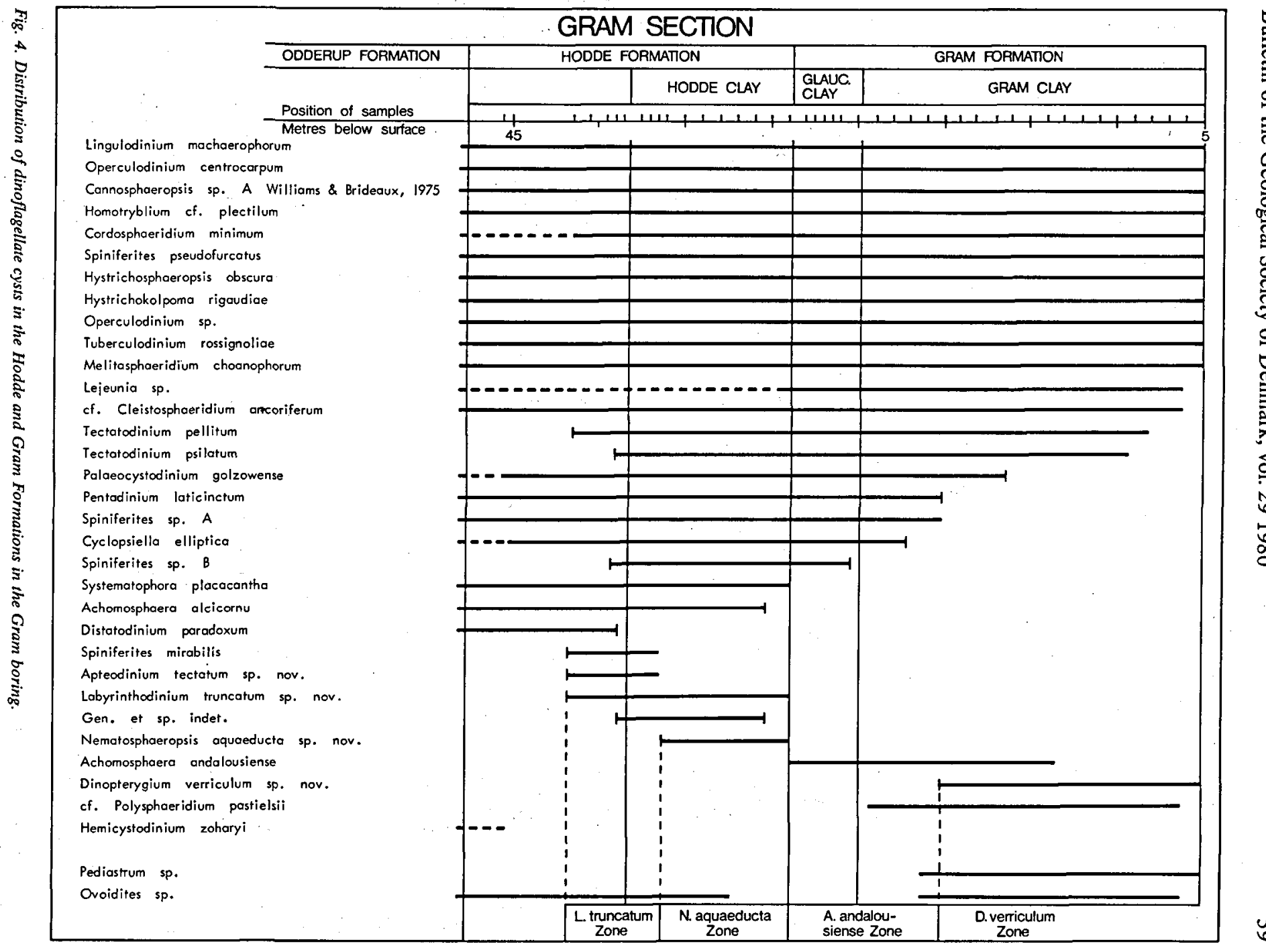




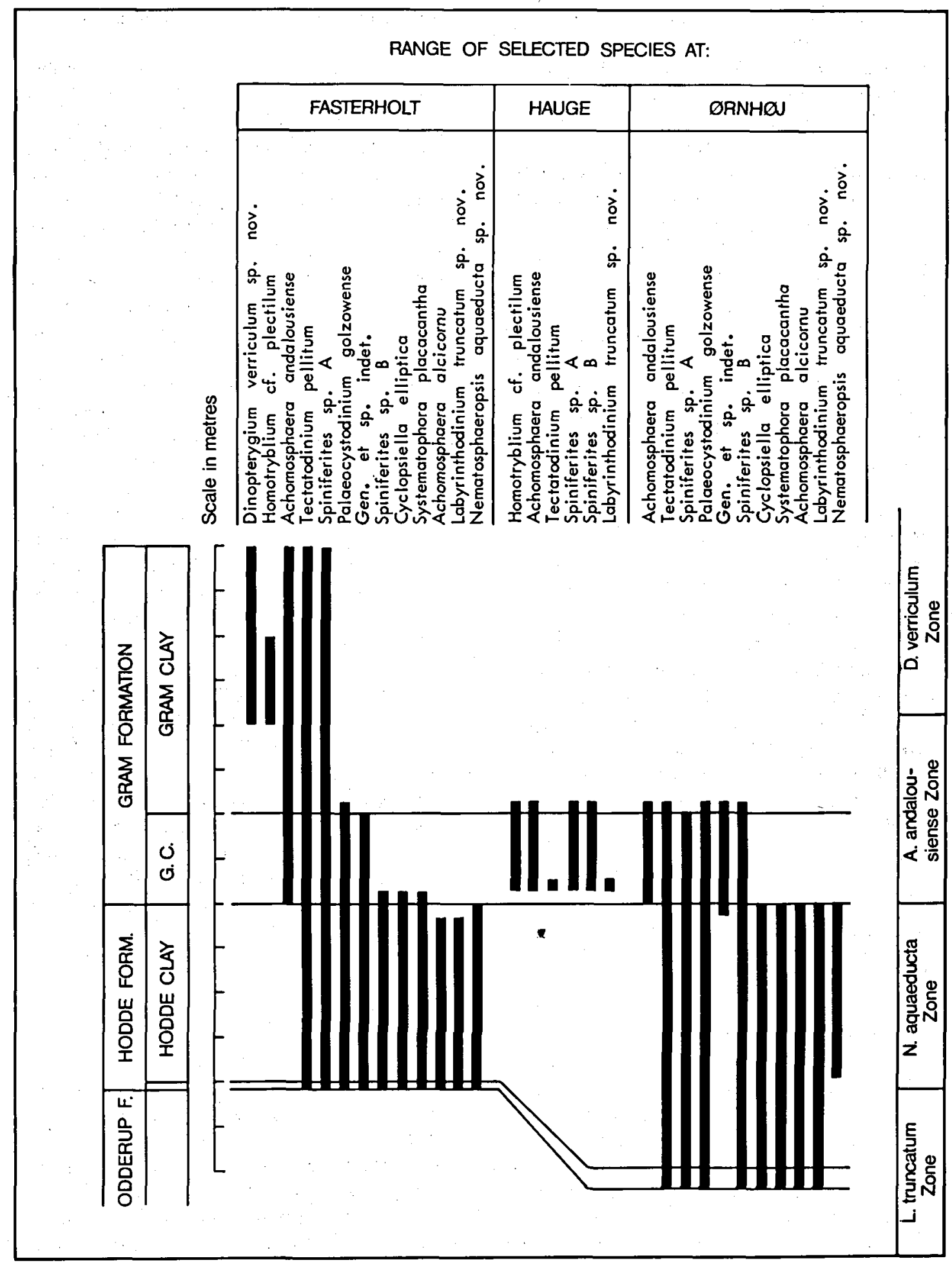

Fig. 5. Distribution of selected dinoflagellate cysts in the Hodde and Gram Formations at Hauge, Fasterholt and $\emptyset$ rnhøj. 
Dinopterygium verriculum Zone nov.

Definition: Sediments containing Dinopterygium verriculum $\mathrm{sp}$. nov. The lower boundary at the first occurrence of $D$. verriculum. The upper boundary is tentatively defined at the last occurrence of $D$. verriculum.

Reference section: Boring at Gram town: DGU file $141423,20.0-5.0$ metres below the surface. Glacial erosion and Quaternary sediments terminate the section upward.

Local correlation: The Dinopterygium verriculum Zone is found in the Gram Formation at Fasterholt from 4 metres above the lower boundary to the top of the sequence.

Stratigraphical range: Upper Miocene above Achomosphaera andalousiense Zone nov.

Remarks: The upper boundary of the zone has not been determined at Gram because the zone is restricted upwards by erosion and mixing with glacial sediments. The last occurrence of Palaeocystodinium golzowense Alberti, 1961 is found in this zone.

The disappearance of T. pellitum, T. psilatum and $A$. andalousiense in the upper part of the Gram sequence is believed to be caused by local environmental changes, as the species are reported from younger sediments (Harland, 1978, Wall, Dale \& Harada, 1973). The dinoflagellate cyst assemblage in the $A$. andalousiense Zone and the $D$. verriculum Zone is dominated by Homotryblium cf. plectilum and in some levels of $D$. verriculum.

\section{Age of the Hodde and Gram Formations}

The number of papers dealing with dinoflagellate cyst stratigraphy in the Miocene is limited. Nevertheless, a number of species have been shown to be of some stratigraphic importance. Harland (1978) published Neogene range charts, based on his own work and the more important papers of Neogene dinoflagellate cyst stratigraphy from the Northwest European continental shelf and adjacent areas. Several species appeared to have a restricted range in the Miocene, but only some of these occur in the Hodde and Gram Formations. There are also differences in the occurrences found in the Hodde and Gram
Formations and the ranges reported by Harland (1978).

The last occurrence of $S$. placacantha (recorded as $S$. ancyrea by Harland, 1978) and the first occurrence of $A$. andalousiense at the boundary between the Middle and Late Miocene (Harland, op.cit.) are considered to be of major importance in dating the Hodde and Gram Formations since both cysts occur frequently in their respective sediments. The distribution of the two species indicate that the boundary between the Hodde and Gram Formations corresponds to the boundary between the Middle and Late Miocene, and confirms previous datings (Rasmussen, 1966). Similarly, Harland (1978) reports $N$. aquaeducta to occur for the first time at the boundary between the Early and Middle Miocene. The first occurrence of this species in the lower part of the Hodde clay therefore may indicate a Middle Miocene age for the Hodde clay and an Early Miocene age for the lower part of the Hodde Formation and the Odderup Formation at Gram. However, Manum (1976) reports a range of $N$. aquaeducta corresponding to the upper part of Middle Miocene only.

On the Grand Banks, New Foundland, Williams \& Brideaux (1975) found the last occurrence of $P$. laticinctum, C. elliptica and $P$. golzowense in the middle of Late Miocene, and Polysphaeridium pastielsii Davey \& Williams, 1966 was found to the end of Late Miocene. This is comparable with the last occurrences of these species at Gram. It should be noted, however, that several other species have a distribution on Grand Banks, which is different from that in the Gram sequence.

\section{Environment}

The use of dinoflagellate cysts as a tool for palacoenvironmental interpretations is as yet very limited. Few investigations of the relation between the dinoflagellate cysts and the palaeoenvironment have been published (Downie et al., 1971). However, the Miocene dinoflagellate cyst assemblages have many species in common with Recent sediments, and the distribution of Recent dinoflagellates and their cysts, mainly in the North Atlantic region, is fairly well known (Reid, 1974, 1977, Harland, 1977 
and Wall, Dale, Lohmann \& Smith, 1977). From these works it is evident that it is mainly the dominating species which may be used to characterize the palaeoenvironment, since the diagnostic species also occurs outside the specific environment. Wall et al. (1977) found several species useful as environment indicators.

The dominating species in the Hodde and Gram Formations ( $S$. placacantha, $H$. cf. plectilum and $D$. verriculum) are not known to occur in Recent sediments. Lingulodinium machaerophorum and Operculodinium centrocarpum, which are well represented through the sequence, are well known in Recent sediments. They are characterized as cosmopolitan species in estuarine and neritic environments respectively (Wall et al., 1977).

Bitectatodinium tepikiense Wilson, 1973 is found in the Hodde clay at $\emptyset$ rnhøj only. Apparently it has a northerly distribution in the Atlantic region, probably preferring temperate to cool temperate conditions (Harland, 1977). Dale (1976) has shown from his study of the Trondheim Fjord and the shelf outside the fjord that $B$. tepikiense occurs at the shelf only and not in the fjord. The occurrence of $B$. tepikiense at $\emptyset$ rnhøj, therefore may indicate somewhat more open marine conditions at this locality during the sedimentation of the Hodde clay than at the other three localities.

The presence of high numbers of dinoflagellate cysts through the main part of the sequence, and the conditions preferred by the species mentioned above, indicate a marine estuarine depositional environment for the Hodde clay, glauconite clay and the lower part of the Gram clay. This is in good accordance with the positions of the localities in embayments close to the coast (eastern margin of present occurrence; Rasmussen, 1966).

T. psilatum is reported to occur in fresh to brackish water in the Black Sea during the late Quaternary (Wall \& Dale, 1973). The occurrence of $T$. psilatum in the Hodde and Gram Formations could mean either that the environment was brackish, or that the cysts were transported into the sea from coastal swamps or lakes. As the cyst assemblage otherwise appears to be marine, the latter explanation is assumed to be correct.

The content of terrestial plant material in the Hodde and Gram Formations is variable, espe- cially in the Gram boring. Three intervals may be distinguished on the basis of the variations in the content of dinoflagellate cysts relative to the content of pollen and spores as well as disseminated cuticles and tracheides. The glauconite clay and the lower 4 metres of the Gram clay contains very small amounts of terrestial plant material, in contrast to the remaining part of the Gram clay, which has a high content of terrestial plant material and decreasing amounts of dinoflagellate cysts toward the top of the sequence. The content of terrestial plant material relative to the content of dinoflagellate cysts, in the Hodde Formation, is intermediate compared to the two intervals mentioned above.

A similar trend appears from the variations in the content of freshwater green algal remains. Ovoidites sp. is common throughout the Hodde Formation, and both Ovoidites sp. and Pediastrum sp. are common in the upper part of the Gram Formation, whereas in the intermediate part of the sequence, these genera have not been recorded. A similar division has not been recognized at the other localities.

As marine cysts are present throughout the sequence at Gram, variation in terrestial plant material content most likely reflects the variation in the amount of freshwater flowing into the sea at Gram, or in other words, changes in the drainage of the coastal land area.

H. zoharyi has been shown to be the cyst of the motile dinoflagellate Pyrodinium bahamense Plate, 1906, which is living in littoral embayments in tropical to subtropical regions (Wall \& Dale, 1969). Fossil B. tepikiense is reported only from temperate to cold temperate regions and its Recent occurrence seems to be restricted to these areas as well (Dale, 1976). The presence of $H$. zoharyi, which is confined to the lowest part of the Hodde Formation at Gram, in contrast with the isolated occurrence of $B$. tepikiense, in the Hodde clay at $\varnothing$ rnhøj only, could indicate a temperature decrease during the sedimentation of the Hodde Formation. This would agree closely with the temperature variation curve recently presented by Buchardt (1978). This curve shows a decrease in temperature from Middle Miocene into Upper Miocene, with a minimum temperature corresponding to the lowermost part of the Gram clay.

It appears from the distribution of the dino- 
flagellate cysts that the lower boundary of the Hodde clay is younger at Fasterholt than at Gram and Ørnhøj. This may be because the Hodde Formation is the basal part of the uppermost Miocene transgression described by several authors (Rasmussen, 1966, Koch et al., 1973, Asgaard \& Bromley, 1974). The upper boundary of the Hodde Formation coincides with the boundary between $N$. aquaeducta Zone and $A$. andalousiense Zone in all the sequences examined. So the termination of the Hodde clay sedimentation seems to have taken place at approximately the same time all over the area. The upper boundary of the Hodde clay is used as a marker horizon in the North Sea basin (Rasmussen, 1974), and on the basis of the present evidence it may be'regarded as an isochrone.

The difference in thickness of the Hodde clay at Fasterholt and at Ørnhøj, reflects the difference in the length of time during which this particular type of sedimentation prevailed. Nevertheless, the increased thickness of the Hodde clay at Gram also reflects a somewhat higher rate of accumulation, because the $N$. aquaeducta Zone is slightly thicker at Gram than at the other localities.

While local variations in the sedimentation rates therefore seem to have been limited during the sedimentation of the Hodde clay, they became more pronounced during the sedimentation of the Gram Formation. The A. andalousiense Zone is twice as thick in the Gram sequence as in Fasterholt sequence. This suggests that the decreasing amount of dinoflagellate cysts in the upper part of the Gram clay at Gram may be caused by a combination of unfavourable environmental conditions (i.e. freshwater influx) and dilution of the assemblage by increased sedimentation rate.

\section{Systematic description}

Only dinoflagellate cysts, which are important to the stratigraphy in this paper, are treated herein. The taxonomy follows that proposed by Stover \& Evitt, 1978.

Apteodinium tectatum sp. nov.

Pl. 2, fig. 1-6.

1977 cf. Pyxidiella Chene, textfig. 4, 9, Pl. 1, fig. 12.
Diagnosis: Spherical to ovoidal Apteodinium with a short and broad apical horn. The wall is differentiated into three units. The middle unit consists either of spongeous tissue with internal channels or short "processes" separating the inner and outer unit. Paracingulum and parasulcus are clearly differentiated. The archaeopyle is precingular: Type $\mathbf{P}$.

Description: Proximate cysts with spherical to ovoidal capsule, with a short and broad apical horn. Three wall layers may be recognized. The endophragma is thick, massive and hyaline, and separated from the periphragma by short "processes", low walls or spongeous tissue with internal channels. All intermediate structures have been observed, but the wall structures are generally uniform in one specimen. The internal walls and processes are buccinate in optical sections because they are expanded proximately and distally. The periphragma is thin and finely foveolate. The thickness of the cyst wall varies from 2 to $6 \mu \mathrm{m}$.

The apical horn is mainly formed by the periphragma and the middle wall unit, but a weak bulge may be present in the endophragma below the horn. The length of the apical horn varies from 2 to $14 \mu \mathrm{m}$.

No parasutural structures have been observed, except for the thickenings of the middle wall unit along the sides of the paracingulum. The Paracingulum and the parasulcus are grooved and the structure of the middle wall unit may be absent in these areas. The paracingulum is helicoidal and narrow. The endo- and periphragma may be in contact in the parasulcal area.

The archaeopyle is pentagonal to trapezoidal and the posterior margin is in contact with the paracingulum. Shape and position of the archaeopyle indicate that it is formed by the loss of paraplate $3^{\prime \prime}$. The archaeopyle formula is $P$.

Discussion: Apteodinium tectatum sp. nov. differs from other species of the genus by the combination of the helicoidal paracingulum, the presence of a well defined parasulcus, the apical horn and the wall structure. The genus Pyxidiella Cooksen \& Eisenack, 1958 has an intercalary archaeopyle and no apical horn.

The homology of wall layers in dinoflagellate cysts is not well understood yet, and the ter- 

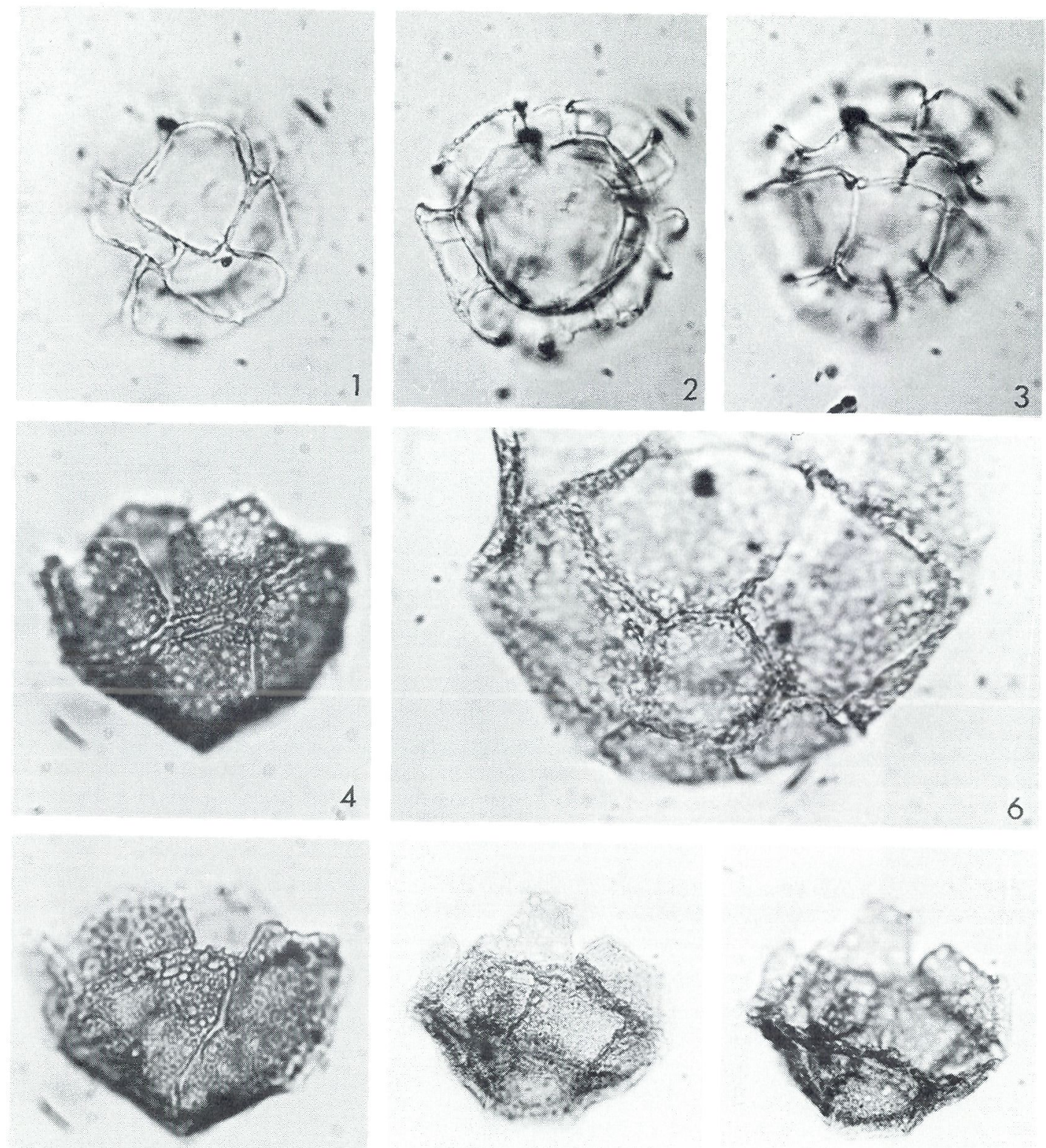

5
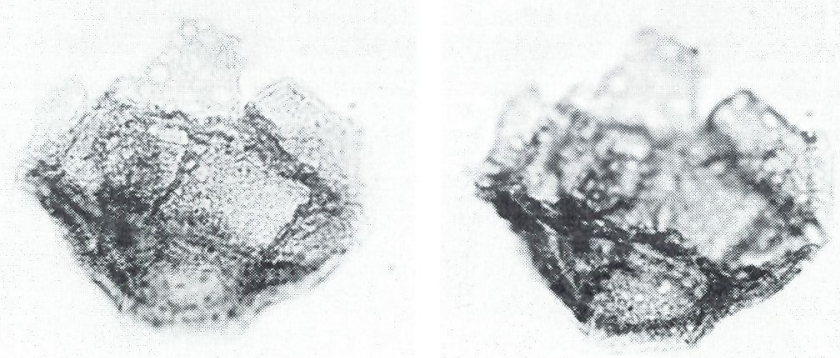

PLATE 1.

Figs 1-3. Nematosphaeropsis aquaeducta sp. nov., holotype, MGUH 14961, high, medium and low focus, $1000 \times$. Figs 48 . Dinopterygium verriculum sp. nov., Figs 4 5. Double parasutures, high and low focus, $500 \times$. Fig. 6. Pentagonal antapical paraplate $1000 \times$. Figs 7-8. Holotype, MGUH 14958, high and low focus, $500 \times$.

PLATE 2.

Figs 1-6. Apteodinium tectatum sp. nov. Figs 1-3. Paratype, MGUH 14957, high, medium and low focus, $500 \times$. Figs 4-6. Holotype, MGUH 14956, high, medium and low focus, $500 \times$. Fig. 7. Cyclopsiella elliptica, $1000 \times$. Fig. 8. Achomosphaera andalousiense, 500 $\times$. Figs 9-11. Labyrinthodinium truncatum gen. nov. sp. nov., holotype, MGUH 14959, high, medium and low focus, $1000 \times$. 

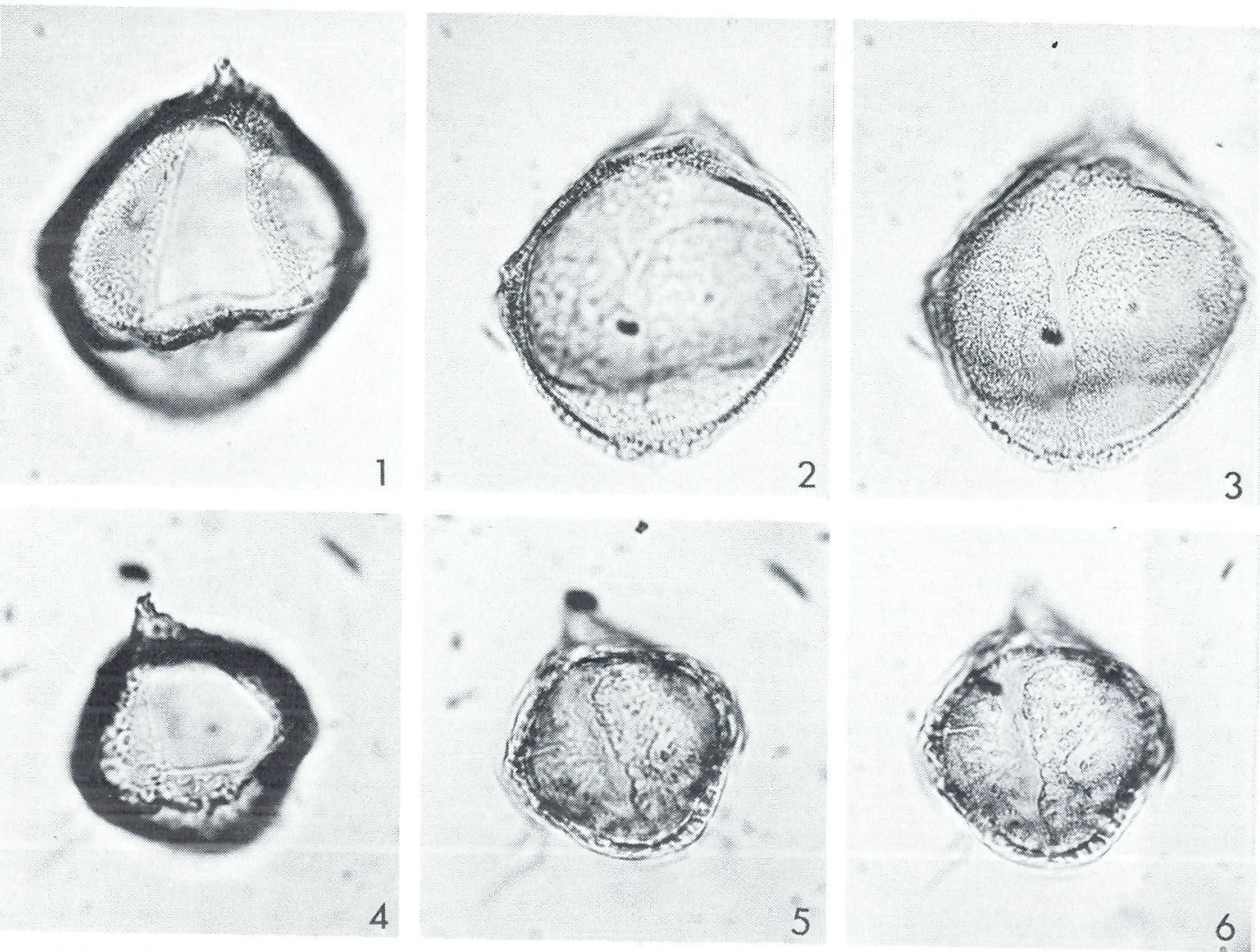

4
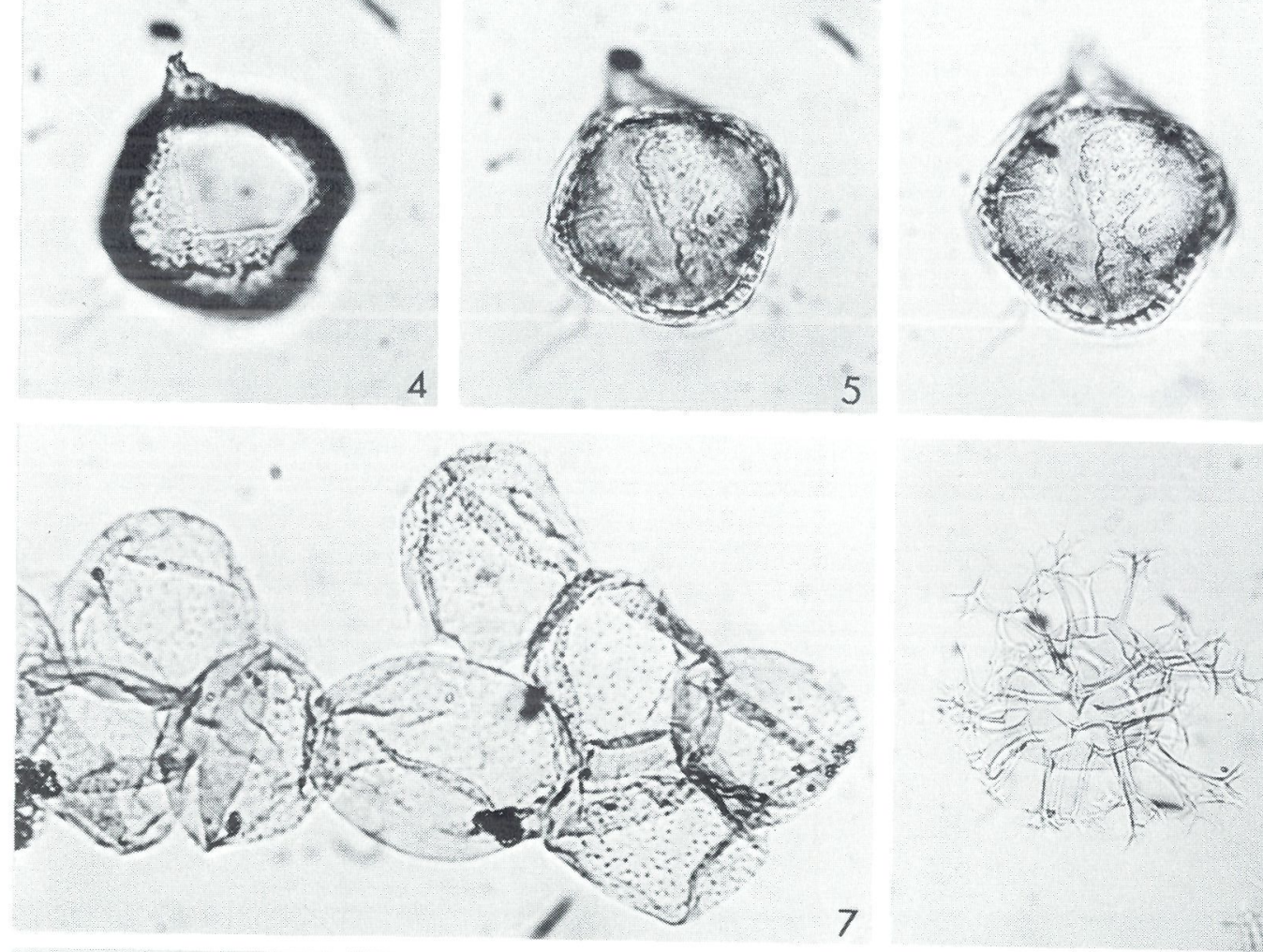

6
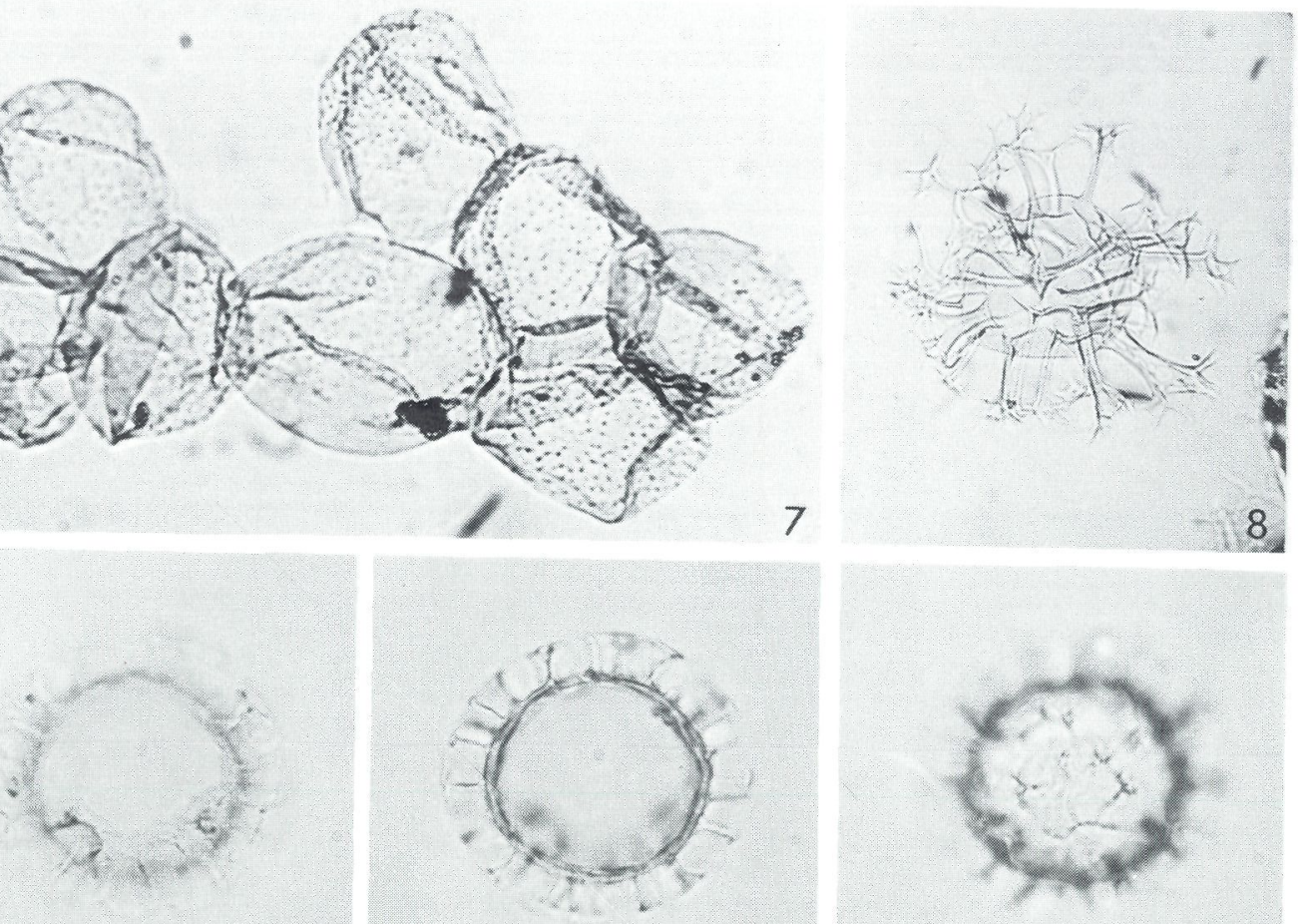
minology (Evitt et al., 1977) is therefore not always definitive. In this case the terminology of the wall layers is dependent on the interpretation of the middle wall unit. I have chosen to regard the wall cavity as being a reduced pericoel, and to regard the structures of the middle wall unit as not being "regular processes", because the middle wall unit also appears as a more common wall structure (spongeous), which may be a part of periphragma. The inner and outer wall layers are therefore endo- and periphragma respectively. The wall of Dinopterygium verriculum sp. nov., which is discussed later in this paper, is interpretated in the same way.

Holotype: Pl. 2, fig. 4-6. Size: length $65 \mu \mathrm{m}$, breadth $59 \mu \mathrm{m}$, length of apical horn $9 \mu \mathrm{m}$. MGUH 14956.

Paratype: Pl. 2, fig. 1-3. Size: length $88 \mu \mathrm{m}$, breadth $77 \mu \mathrm{m}$, length of apical horn $6 \mu \mathrm{m}$. MGUH 14957.

Size variation: $(n=15)$ length 63 (74) $90 \mu \mathrm{m}$, breadth 51 (62) $77 \mu \mathrm{m}$, length of apical horn 2 (6) $14 \mu \mathrm{m}$.

Type locality and type stratum: Denmark, Gram, Gram boring (DGU file 141423) 42.0-35.5 m below surface, Hodde Formation.

Stratigraphical range: Middle Miocene, Labyrinthodinium truncatum Zone and Nematosphaeropsis aquaeducta Zone.

Cannosphaeropsis sp. A. Williams \& Brideaux, 1975.

1975 Cannosphaeropsis sp. A. Williams \& Brideaux: Pl. 15, fig. 4, Pl. 17, fig. 10.

Remarks: A number of cysts in the Gram sequence correspond in size as well as morphology to the species figured by Williams \& Brideaux (1975). The processes are branched distally several times into extremely delicate threads, which are easily broken and hardly visible. It has been difficult to find specimens, which, without doubt, have these threads connected from one process to another as trabeculae. The cysts are also very similar to the specimens figured by Manum (1976) as Impletosphaeridium rugosum Morgenroth, 1966 and Impletosphaeridium sp. 1, because the processes may or may not possess a distal platform from which the branching occurs. In other characters, however, these cysts do not fit into the diagnose of $I$. rugosum. The type of archaeopyle has not been determined.

Dimensions: $(n=15)$ Diameter of capsule 18-28 $\mu \mathrm{m}$, length of processes $12-18 \mu \mathrm{m}$.

Dinopterygium verriculum sp. nov. Pl. 1, fig. 4-8, Pl. 5, fig. 5-6.

Diagnosis: A species of Dinopterygium with thin, hyaline wall layers, separated by pillars or low membranes, forming a reticulate pattern. The outer wall layer may form low fenestrated parasutural membranes, but no large and extending cingular membranes are present. The archaeopyle is epicystal; Type $\mathrm{tA}+\mathrm{tPa}$.

Description: A proximate to proximochorate cyst, with a rounded to pentagonal shape in aequatorial view, and ovoidal shape with the parasulcal area slightly grooved in polar view.

The cyst wall is differentiated into three units. Endophragma and periphragma are thin and hyaline, and separated by short "processes" or low membranes. A spongeous tissue occurs very seldom. The middle wall unit form a reticulate pattern with varying mesh size. The surface of the cyst is smooth or finely punctate.

The paratabulation may be determined from variations in the structure between endo- and periphragma or from parasutural membranes formed by upfolding of the periphragma. The parasutural membranes on the surface of the cyst are 1 to $2 \mu \mathrm{m}$ high, but occasionally up to $6 \mu \mathrm{m}$ high. They are densely perforated. The paracingulum and parasulcus are not differentiated into paraplates except for paraplate ps. The paratabulation formula is determined to be $\left(3(4)^{\prime}, 6^{\prime \prime}\right.$, ?c, $\left.5^{\prime \prime \prime}, \mathrm{ps}, 1 \mathrm{p}, 1^{\prime \prime \prime \prime}\right)$. The apical paraplates have only been observed on one occasion, because the epicyst is disintergrated into single paraplates during archaeopyle formation, and only excysted specimens have been found. The paracingulum is slightly helicoidal, and the parasulcus is slightly grooved. The position of paraplates $p s$ and $\mathrm{lp}$ and the shepe of $1^{\prime \prime \prime \prime}$ indicate a pyrodinium-type of tabulation (Evitt, 1976). The archaeopyle is epicystal and the archaeopyle formula is tA+tPa. Varying numbers of precingular paraplates may remain attached to the hypocyst after the ar- 
chaeopyle formation. The parasulcus form a minor sulcal flap at the margin of the hypocyst.

Discussion: Dinopterygium verriculum sp. nov. differs from other species of the genus by the wall structure and by the absence of a single compound operculum.

Holotype: Pl. 1, fig. 7-8. Size: length $63 \mu \mathrm{m}$ excl. apical area, breadth $77 \mu \mathrm{m}$. MGUH 14958.

Size variation: $(n=25)$ length $51(56) 6 \mu \mathrm{m}$ excl. apical area, breadth 50 (62) $77 \mu \mathrm{m}$.

Type locality and type stratum: Danmark, Gram, Gram boring (DGU file 141 423), 20.0-5.0 m below surface, Gram Formation.

Stratigraphical range: Upper Miocene, Dinopterygium verriculum Zone.

Labyrinthodinium gen. nov.

Pl. 2, fig. 9-11, Pl. 3, fig. 2, Pl. 6, fig. 3-4.

Diagnosis: Small chorate cysts with spherical main body and apical archaeopyle. The cyst wall is two layered, and periphragma forms a closed or open reticulum of anastomosing crests. The smaller crests support the larger ones, which form membraneous processes of equal length.

Type species: Labyrinthodinium truncatum gen. nov. sp. nov.

Remarks: Labyrinthodinium gen. nov. is similar to the Upper Jurassic genus Epiplosphaera Klement, 1960, but the reticulum on the cyst surface of Labyrinthodinium is not as well developed as in Epiplosphaera. The spherical main body and the membraneous processes are also different from Epiplosphaera, and a large time gap is furthermore separating the two genera.

Labyrinthodinium truncatum $\mathrm{sp}$. nov.

Pl. 2, fig. 9-11, Pl. 3, fig. 2, Pl. 6, fig. 3-4.

1976 Cordosphaeridium sp. 2 Manum, Pl. 3, fig. 4-5.

Diagnosis: Small chorate cysts with spherical main body, composed of two wall layers. Endophragma is hyalin and structureless, Periphragma is smooth to spongeous at the surface of the main body, and smooth with scattered microgranulaes when forming crests and processes. Periphragma forms an open reticulum of crests from which membraneous processes arise. All the processes are of equal length and slightly expanded distally into small platforms. The archaeopyle is large and polygonal of type $\bar{t} \bar{A}$.

Description: Endophragma is of constant thickness, while periphragma may be thin and smooth or thick and spongeous. The wall thickness range from 1-3 $\mu \mathrm{m}$, mainly because of the variation of periphragma. The two wall layers are not clearly separable when periphragma is thin and smooth.

The crests on the surface of the cysts may either form a dense reticulum with a large number of processes or a rude pattern with open meshes and few processes. The reticulum may reflect a undeterminable paratabulation, because some of the crests appear to form a superior pattern from which the processes arise. Further, the archaeopyle sutur does not cross the crests, which are conformable with the archaeopyle margin and partly with the accessory archaeopyle sutures.

The processes are formed of several adjoining crests or membranes, and are all of the same length on one cyst. They are expanded distally, building up a small platform.

No structures reflecting paratabulation, paracingulum or parasulcus have been observed, except for the archaeopyle sutures. The archaeopyle is apical: type $\bar{t} \bar{A}$. It is large and polygonal, and small accessory sutures are present along the margin.

Discussion: These cysts do not belong to Cordosphaeridium (Eisenack) Davey, 1969, because they do not have intratabular fibrous processes and a precingular archaeopyle.

Holotype: Pl. 2, fig. 9-11. Diameter $25 \mu \mathrm{m}$, length of processes $5 \mu \mathrm{m}$, wall thickness $1 \mu \mathrm{m}$. MGUH 14959.

Paratype: Pl. 3, fig. 2. Diameter $40 \mu \mathrm{m}$, length of processes $10 \mu \mathrm{m}$, wall thickness $3 \mu \mathrm{m}$. MGUH 14960.

Size variation: $(\mathrm{n}=30)$ Diameter $23(29) 40 \mu \mathrm{m}$, length of processes 4 (6) $10 \mu \mathrm{m}$, wall thickness 1-3 microns.

Type locality and type stratum: Denmark, Gram, Gram boring (DGU file 141423 ) 42.0-29.0 m below surface, Hodde Formation.

Stratigraphical range: Middle Miocene, 

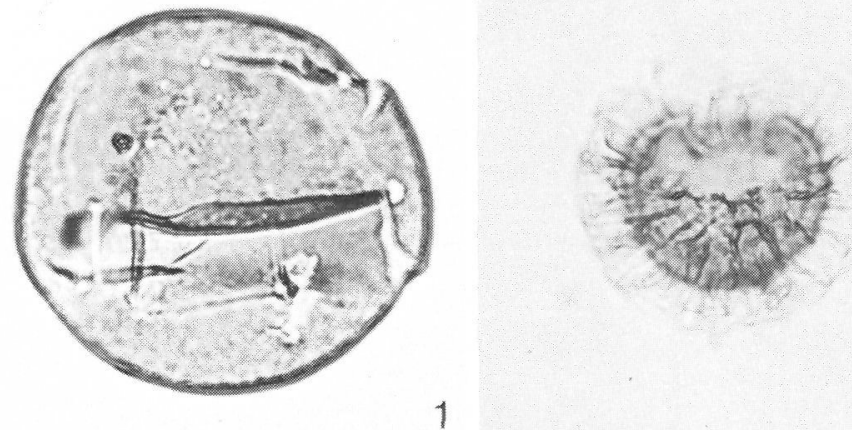

2

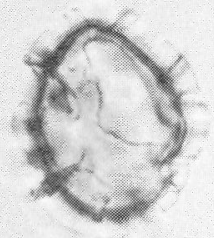

1
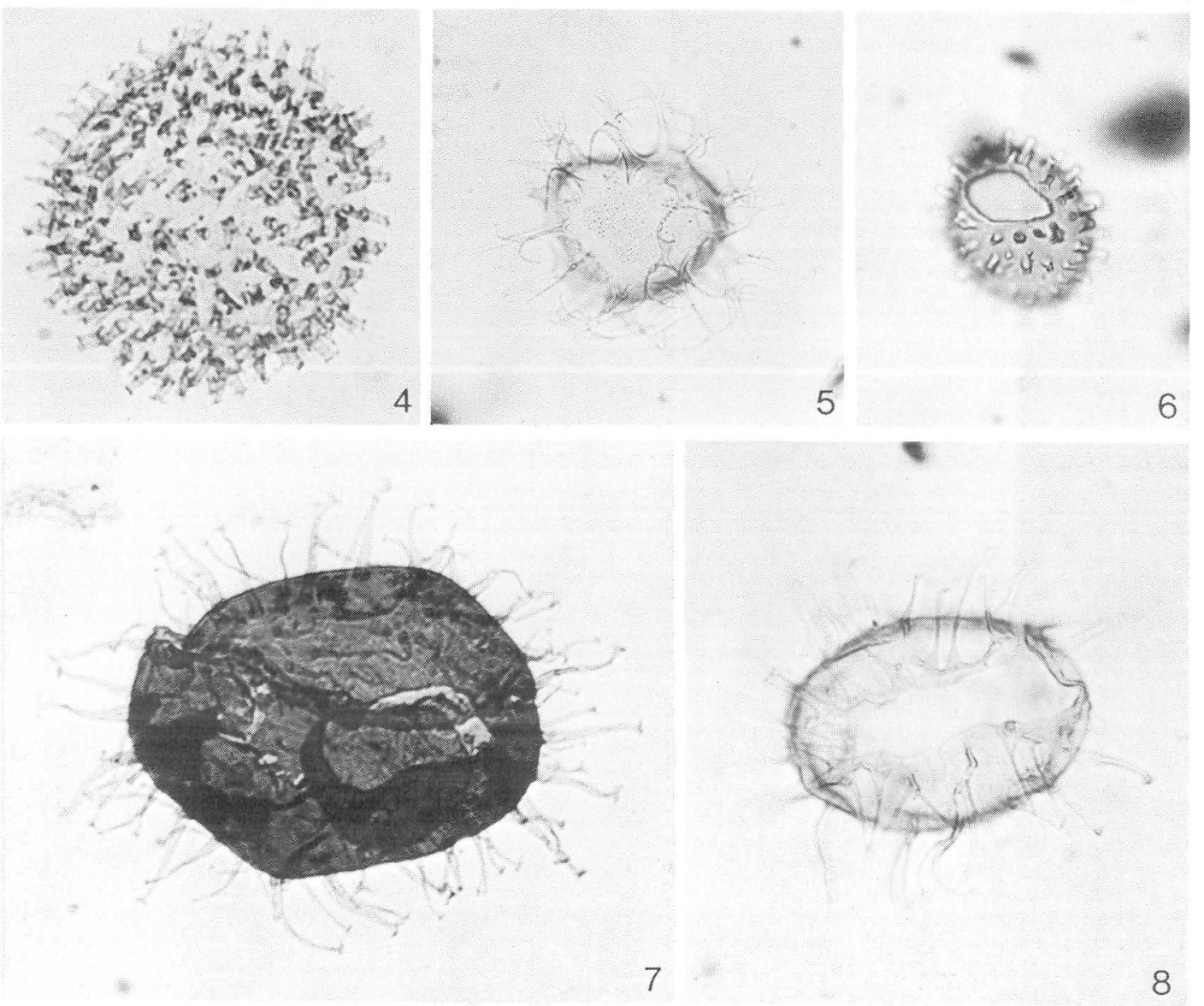

PLATE 3.

Fig. 1. Bitectatodinium tepikiense, $500 \times$. Fig. 2. Labyrinthodinium truncatum gen. nov. sp. nov., paratype, MGUH $14960,500 \times$. Fig. 3. Gen. et sp. indet., 500 ×. Fig. 4. cf. Cleistosphaeridium ancoriferum, $500 \times$. Fig. 5. Spiniferites $s p$. A, $500 \times$. Fig. 6. Operculodinium sp., 500 ×. Fig. 7. cf. Polysphaeridium pastielsii, $500 \times$. Fig. 8. Systematophora placacantha $500 \times$.

\section{PLATE 4.}

Fig. 1. Tectatodinium pellitum $500 \times$. Figs 2-3. Tectatodinium psilatum $500 \times$. Fig. 4. Pediastrum sp. $500 \times$. Fig. 5. Ovoidites $s p$. $500 \times$. Figs 6-7. Fungi $500 \times$. 

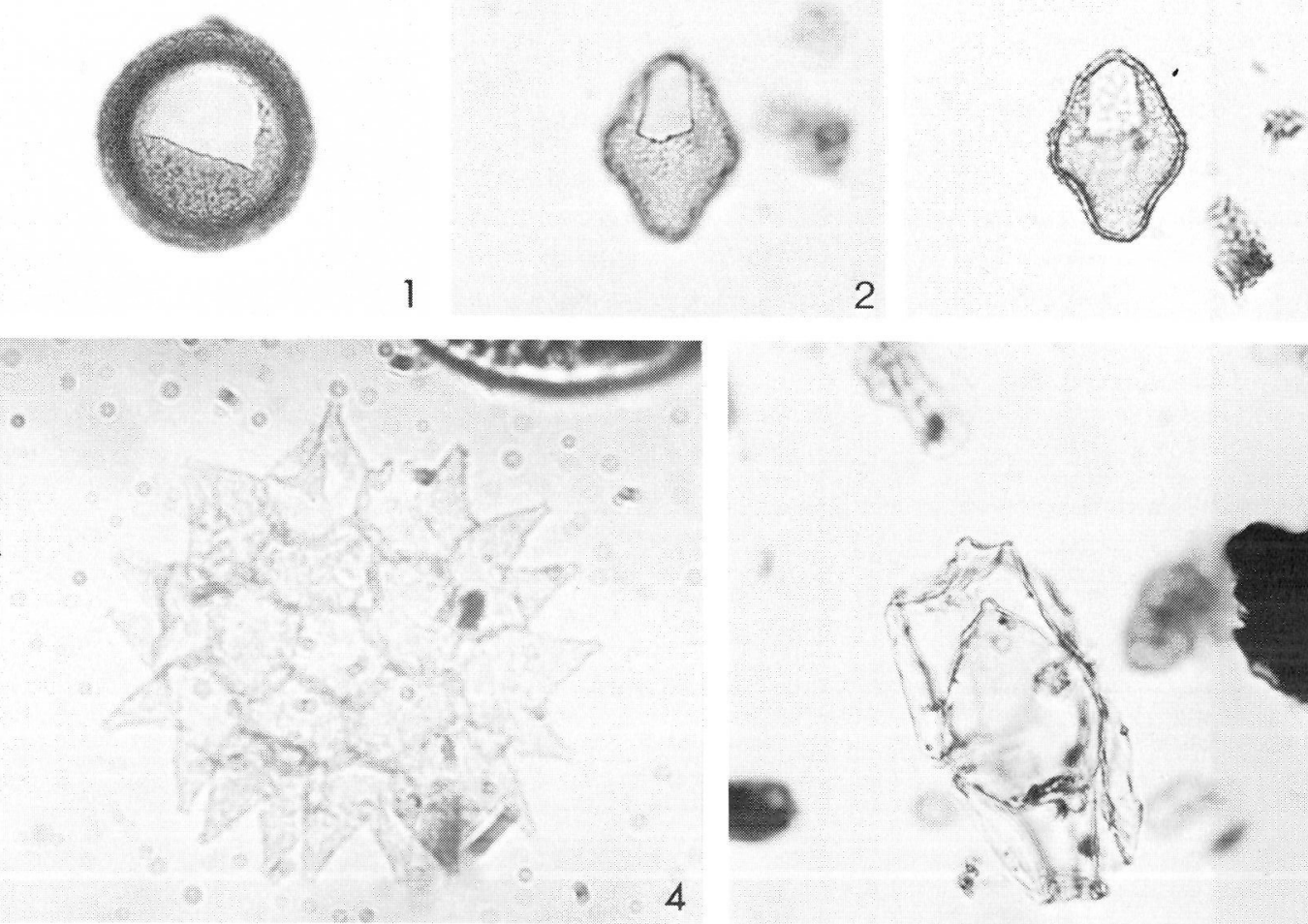

\section{2}
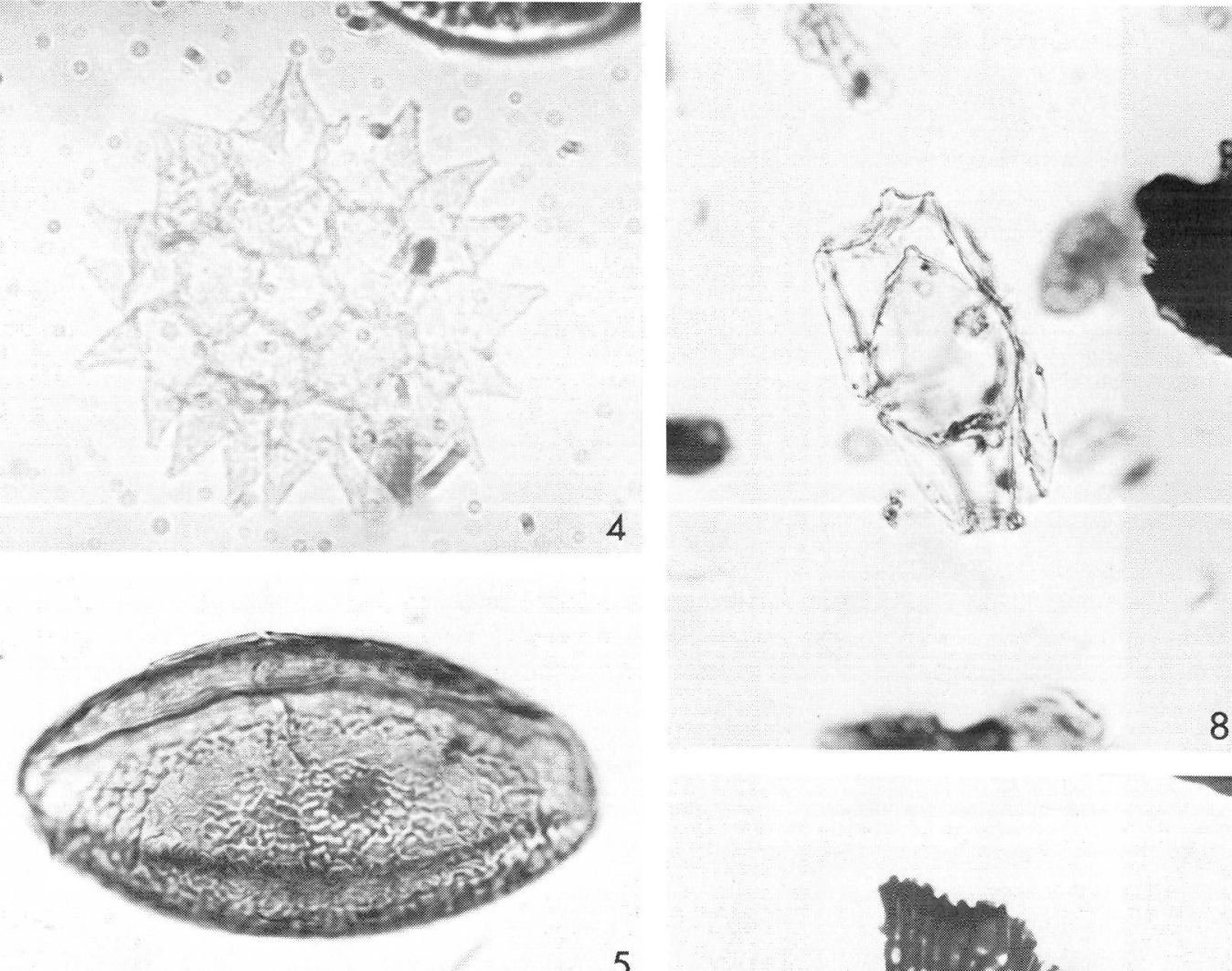

5
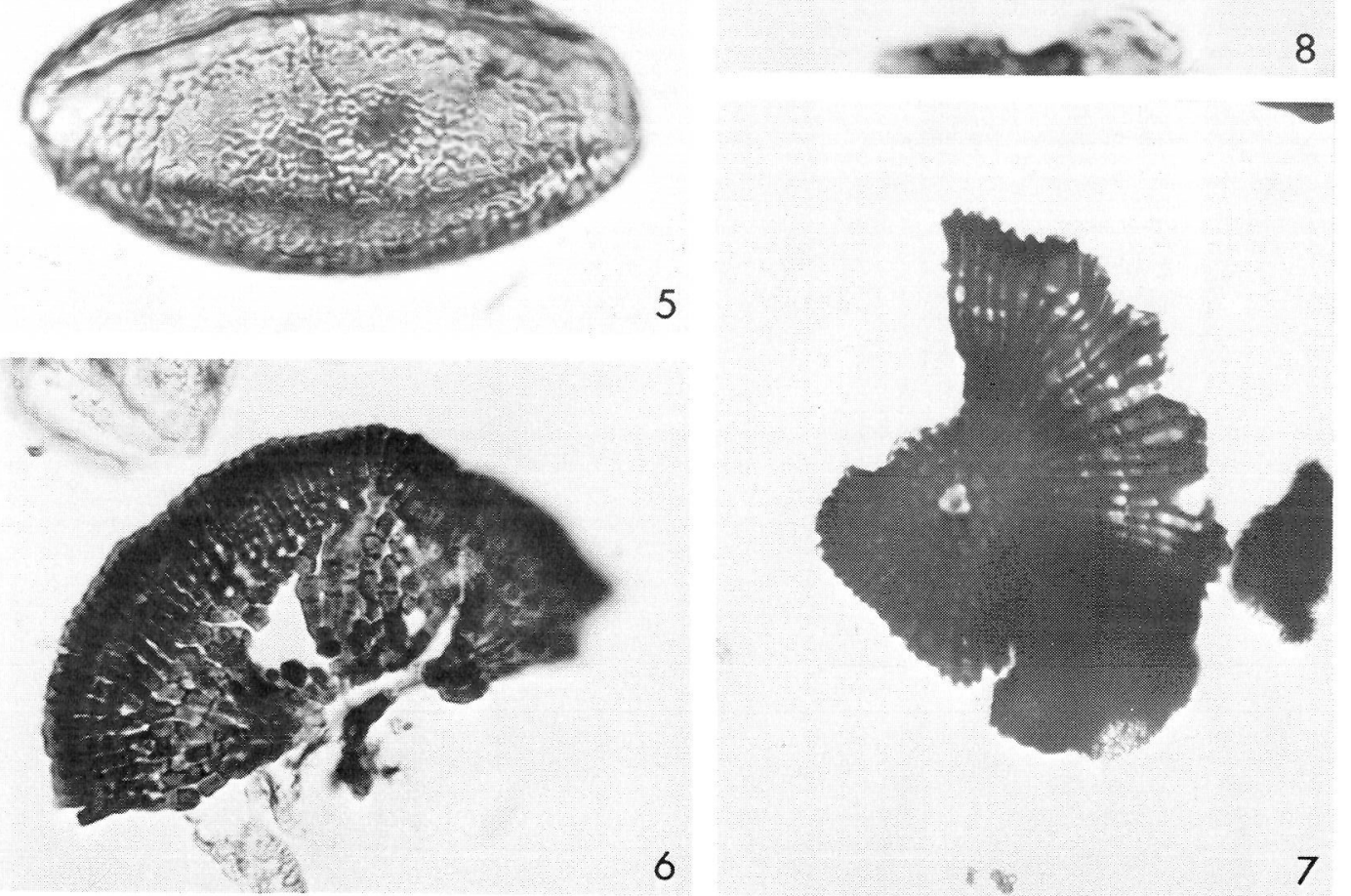

6

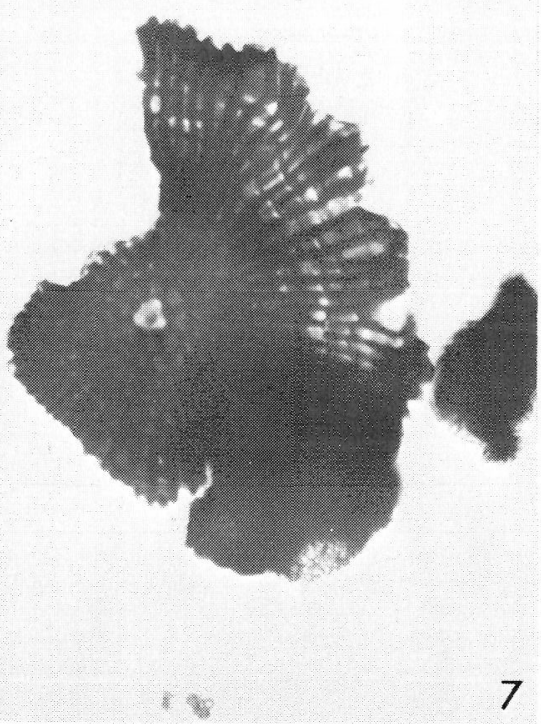


Labyrinthodinum truncatum Zone and Nemathosphaeropsis aquaeducta Zone.

Hystrichosphaeropsis obscura Habib, 1972.

Pl. 4, fig. 8.

1972 Hysterichosphaeropsis obscura Habib, p. 379-380, Pl. 21, fig. 1-3.

Remarks: A few morphological variations, which have not been mentioned in the description of this species (Habib, 1972), have been observed. Specimens with reduced epi- and hypocoels have been found. The sculpture of both peri- and endophragma may be coarsely granular or completely smooth. The endocyst may possess a small massive, hyaline apical horn.

Nematospheropsis aquaeducta sp. nov.

Pl. 1, fig. 1-3, Pl. 5, fig. 1-2.

1969 Nematosphaeropsis balcombiana: Baltes, Pl. 3, fig. 1-3.

1976 Leptodinium sp. 5 Manum: Pl. 1, fig. 19-20.

Diagnosis: A Nematosphaeropsis with short and stout processes connected distally by stout trabeculae, which are triangular in cross section. Parasutural structures are missing on the central body.

Description: Chorate cysts with spherical to slightly ovoidal central bodies and sutural processes and trabeculae forming an outer sphere. Only one wall layer is visible in the light microscope. No structures are visible in the wall. The surface is smooth or punctate.

Gonal and intergonal processes are present and no parasutural structures connect the bases of the processes. A few of the processes show a small proximate cavity, otherwise they are massive and buccinate. The processes are short and stout, and angular in cross section. Distally they expand into connecting trabeculae, which make the paratabulation clearly visible. The trabeculae are triangular in coss section with one angle pointing against the capsule. The outer side of the trabeculae is concave, especially above the processes, giving rise to a shape similar to the shape of the roman aquaducts. The length of the processes are 9-12 $\mu \mathrm{m}$, and uniform within a single specimen.

The archaeopyle is formed by the loss of paraplate $3^{\prime \prime}$ and the operculum is completely detached. The archaeopyle formula is P. The paratabulation formula, determined from the arrangement of the trabeculae, is $\left(4^{\prime}, 6^{\prime \prime}, 6 \mathrm{c}, 5^{\prime \prime \prime}\right.$, $\left.1 \mathrm{p}, 1^{\prime \prime \prime \prime}\right)$. Paracingulum is helicoidal.

Discussion: Nematosphaeropsis aquaeducta sp. nov. differs from other species of the genus Nematosphaeropsis by its short, simple and stout processes and trabeculae. Baltes (1969) figures a specimen identified as Nematosphaeropsis balcombiana Deflandre \& Cookson, 1955. However, it appears from the figures that this specimen has the short and stout processes and trabeculae here used to define $N$. aquaeducta sp. nov. instead of the long and thin processes and trabeculae typical of $N$. balcombiana. The age of the specimen is Tortonian.

Manum (1975) figured a specimen similar to $N$. aquaeducuta sp. nov. and identified it as Leptodinium sp. 5. The genus Leptodinium is defined as having sutural crests, so, therefore, this species cannot be included in the genus.

Holotype: Pl. 1, fig. 1-3. Size: Total, length 39 $\mu \mathrm{m}$, breadth $38 \mu \mathrm{m}$. Central body, length $27 \mu \mathrm{m}$, breadth $26 \mu \mathrm{m}$ MGUH 14961.

Size variation: $(n=15)$ Total, length $38(40) 47$ $\mu \mathrm{m}$, breadth 32 (36) 45 . Central body, length 27 (32) $37 \mu \mathrm{m}$, breadth 24 (29) $36 \mu \mathrm{m}$.

Type locality and type stratum: Denmark, Gram, Gram boring (DGU file 141 423) 36.0-29.0 m below surface, Hodde Formation.

Stratigraphical range: Middle Miocene, Nematosphaeropsis aquaeducta Zone.

\section{Operculodinium sp.}

PI. 3, fig. 6 .

Remarks: A small ovoidal cyst with precingular archaeopyle. The surface is smooth and covered with short, massive, subconical processes, probably intratabular in position. As Operculodinium species may have 1,2 , or 3 precingular paraplates involved in the archaeopyle formation, this species may correspond to Operculodinium $\mathrm{sp} .2$ Manum, 1976, Pl. 1, fig. 21, which has a 2P archaeopyle.

Dimensions: $(n=12)$ Length of capsule 33-39 $\mu \mathrm{m}$, length of processes $3-5 \mu \mathrm{m}$.

Palaeocystodinium cf. golzowense Alberti, 1961. Remarks: Palaeocystodinium cf. golzowense from 
the Hodde and Gram Formations differs from the type material with respect to its size and weak granulation of the distal part of the apical horn. Alberti (1961) did not report cysts shorter than 125 microns. The length of $P$. cf. golzowense in this material is $90-140 \mu \mathrm{m}$, and the majority of the specimens are between $100-120 \mu \mathrm{m}$, long. The antapical horn may have a sudden reduction in thickness approximately at the middle.

Morphologically this may correspond to the small second antapical horn which is present in some Palaeocystodinium species, as f. inst. $P$. benjaminii and $P$. australinum.

\section{Spiniferites sp. A.}

Pl. 3, fig. 5.

Description: A Spiniferites with extremely variable morphology. The capsule is spherical to ovoidal. Periphragma and endophragma are thin, smooth and structureless; but endophragma may be densely foveolate - vesiculate. Periphragma may form low sutural thickenings or be folded up into membranes, which may be so broad that the periphragma is in contact with the endophragma only in small areas in the middle of the paraplates. On the other hand cysts have been observed without parasutural structures at all.

The processes are massive and trifurcate distally. A varying number of vesicles, but generally one or two, are present at approximately the middle of the process stem, which may bulge out. The vesicles may be restricted to a few of the processes or be completely absent. The cavity from the sutural membrane may reach into the proximal part of the process, disappearing rapidly. A small proximate cavity may be present when no sutural structures are present. The processes are generally round in cross section, but specimens with processes which are triangular in cross section have been found.

The paratabulation has been determined as (3(4)', 6", 6c, 5'". 1p, $\left.1^{\prime \prime \prime \prime}\right)$. The archaeopyle is precingular: Type $P$.

Discussion: The spectacular property of these cysts, the vesicles in the process stem, cannot be used as diagnostoc character because similar structures are noted in a number of other species: Spiniferites hyperacanthus (Deflandre \& Cookson) Cookson \& Eisenack, 1974, Pl. 22, fig. 1,
Hysterichosphaera crassipellis Gerlach, 1961, Abb. 16, 17, 22 (now Achomosphaera) and Hafniasphaera hyalospinosa Hansen, 1977.

Dimensions: $(n=10)$ Length of capsule 36-45 $\mu \mathrm{m}$, length of processes $17-26 \mu \mathrm{m}$, wall thickness 1-2 $\mu \mathrm{m}$.

Spiniferites sp. B.

Pl. 6, fig. 2.

Description: A very thin walled Spiniferites with processes of the same type as Spiniferites pseudofurcatus (Klumpp) Sarjeant, 1970, but with very high parasutural membranes connecting the processes. The membranes may be as high as the processes, which then are without distal trifurcation. Scattered fenestrae occur at the membranes. The determination of the paratabulation is difficult, because of the very thin periand endophragma, but is supposed to be (?', $6^{\prime \prime}$, $\left.6 c, 5^{\prime \prime \prime}, 1 " \prime \prime\right)$. A superficial similarity to Spiniferites cruciformis Wall \& Dale, 1973 may occur, due to the morphology and distribution of the processes. However, a cruciform capsule has never been observed. The archaeopyle is precingular: Type $P$.

Dimensions: $(n=18)$ Length of the capsule $18-40 \mu \mathrm{m}$, length of processes $12-20 \mu \mathrm{m}$.

Gen. et sp. indet.

Pl. 3, fig. 3, Pl. 6, fig. 5-6.

Remarks: A small spherical to ovoidal cyst with precingular archaeopyle. The surface is finely granular and covered with discontinuous crests, probably reflecting paratabulation.

Dimensions: $(n=10)$ Length of capsule $28-36 \mu \mathrm{m}$, wall thickness $1-2 \mu \mathrm{m}$, height of crests 4-6 $\mu \mathrm{m}$.

Other algae.

Ovoidites (Potonié) Krutzch, 1959.

Ovoidites sp.

Pl. 4, fig. 5.

Remarks: The genus Ovoidites has been shown to be the zygospore of zygnematacean greenalgae Spirogyra sp. (van Geel, 1976 and van Geel \& van der Hammen, 1978). As the Zygnematales occur in freshwater only, the zygospore formation must occur in freshwater only, the zygospore formation must occur in freshwater and Ovoidites sp. in the present material must have been transported into the sea. 

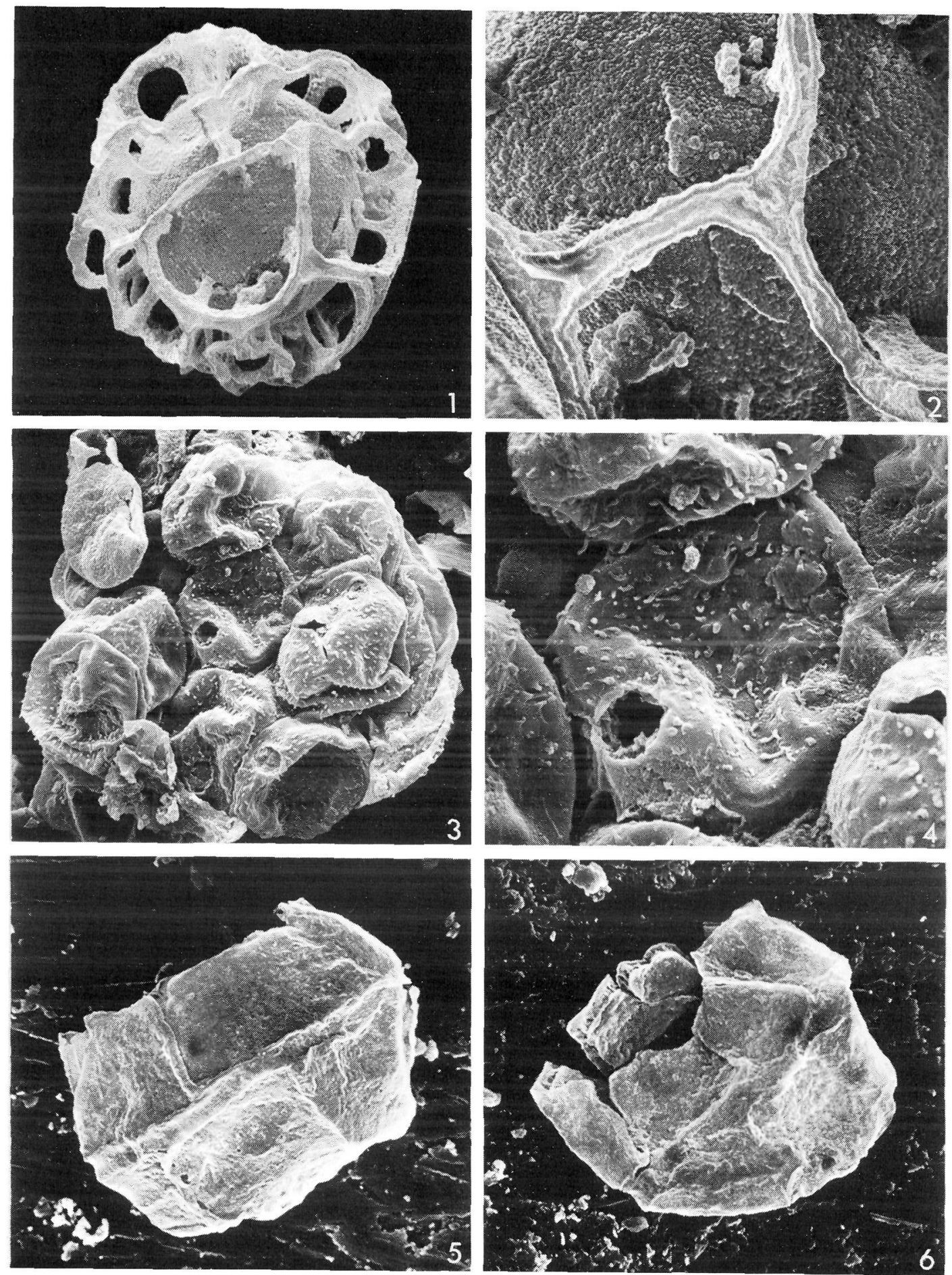

PLATE 5

Figs 1-2. Nematosphaeropsis aquaeducta sp. nov. Fig. 1. Dorsal view $1650 \times$. Fig. 2. Trabeculae $4100 \times$. Figs 3-4. Cyclopsiella elliptica. Fig. 3. Aggregated group $580 \times$. Fig. 4. Aperture and surface sculpture $1600 \times$. Figs 5-6. Dinopterygium verriculum sp. nov. Fig. 5. $870 \times$. Fig. 6. Wall structure $1050 \times$. 

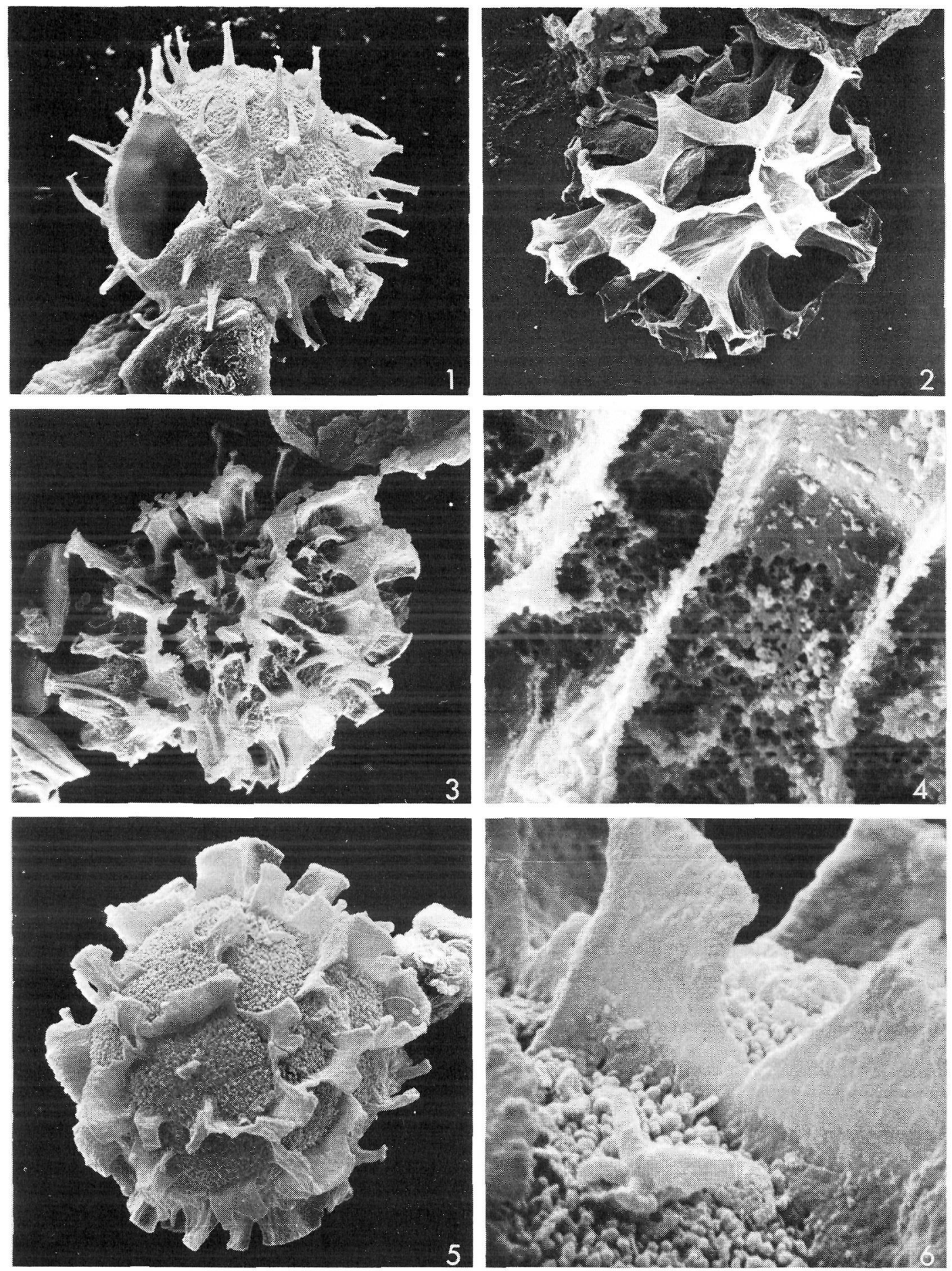

PLATE 6

Fig. 1. Operculodinium centrocarpum $900 \times$. Fig. 2. Spiniferites $s p$. B $1000 \times$. Figs 3-4. Labyrinthodinium truncatum gen. nov. sp. nov. Fig. 3. $1300 \times$. Fig. 4. Details of surface and processes $9000 \times$. Figs 5-6. Gen. et sp. indet. Fig. 5. $1800 \times$. Fig. 6. Details of surface and membranes $9000 \times$. 
Pediastrum Meyen, 1829.

Pediastrum sp.

Pl. 4, fig. 5.

Remarks: The coenobia of the planktonic, freshwater greenalgae Pediastrum has been recorded from Cretaceous to Recent in sediments deposited in marine environment (Evitt, 1963). As was the case with Ovoidites sp. this material must have been transported into the sea.

Fossil Fungi.

Pl. 4, fig. 6-7.

Remarks: Fungal spores occur in many samples but have not been recorded in any detail. Larger remains, very similar to the fruit bodies reported by van Geel \& van der Hammen (1978), are less common but include their Type 8F cf. Stromiopeltis as well as Type 8E.

Incertae sedis.

Cyclopsiella elliptica Drugg \& Loeblich, 1967.

Pl. 2, fig. 7, Pl. 5, fig. 3-4.

1967 Cyclopsiella elliptica, Drugg \& Loeblich, p. 190, Pl. 3, fig. 1-6.

Remarks: Cyclopsiella elliptica is found both as isolated specimens and aggregated into larger groups. The larger groups are typically well organized, and may be regarded as some kind of colonial structure in which the individuals are arranged in a double layered plate comprising up to 30 individuals. The surface of the individuals bear only spines in the areas which are not in contact with another individual. The area covered with spines seems to vary in size on single individuals. When the aperture is visible, it is always situated in the area covered with spines.

Acknowledgements. The author wishes to thank E. Håkansson for long and helpful discussions, and R. Harland and $H$. Gocht for valuable criticism. The Geological Central Institute, University of Copenhagen, is thanked for permission to use the facilities and the scanning electron microscopes of the Laboratory of Electron Microscopy. Diana Bathurst kindly improved the English text and $H$. Egelund made the drawings. The study was supported by the Danish Natural Science Research Foundation.

\section{Dansk sammendrag}

Hodde og Gram Formationerne er aflejret under den sidste Miocane transgression ind over vest Jylland. Formationerne er let genkendelige på grund af rækkefølgen af sort, bituminøst Hodde ler efterfulgt af grønt glaukonitisk ler og brunt til gråt fossilrigt Gram ler. Denne marine lagserie indeholder velbevarede dinoflagellat cyster i store mængder. På grundlag af ensartede variationer $i$ indholdet af dinoflagellate cyster på de fire lokaliteter, hvor formationerne er blottet i dag, er der opstillet 4 biozoner, som forventes at være anvendelige i Nordsø bassinet. En ny slægt og fire nye arter beskrives. I overensstemmelse med tidligere dateringer på grundlag af mollusker dateres Hodde Formationen på grundlag af dinoflagellat cyster til at vare af Mellem Miocæen alder og Gram Formationen til at være af Øvre Miocan alder.

Aflejringsmiljøet antages at være estuarint under delvis indflydelse af tilstrømmende ferskvand, især $i$ den øverste del af Gram Formationen. En generel aftagen af temperaturen $i$ løbet af aflejringen af Hodde Formationen antydes af cyste indholdet.

\section{References}

Alberti, G. 1961: Zur Kenntnis mesozoischer und alttertiärer Dinoflagellaten und Hystrichosperideen von Nord- und Mitteldeutschland sowie einigen anderen europäischen Gebieten. Palaeontographica, Abt. A, 116: 1-58.

Asgaard, U. and Bromley, R. G. 1974: Sporfossiler fra den mellem miocæne transgression i Søby-Fasterholt området. Dansk geol. Foren., Arsskrift for 1973: 11-19.

Baltes, N. 1969: Distribution stratigraphique des dinoflagellés et des acritarches tertiaires en Roumanie. In Brönnimann, P. and Renz, H. H., eds.: Proceedings First International Conference Planktonic Microfossils, Geneva 1967, vol. 1: 26-45.

Benedek, P. N. 1972: Phytoplanktonten aus dem Mittel- und Oberoligozän von Tönisberg (Niederrheingebiet). Palaeontographica, Abt. B, 137: 1-71.

Brosius, M. 1963: Plankton aus dem nordhessischen Kasseler Meeressand (Oberoligozān). Deutsch. Geol. Gesell., Zeitsch., 114: 32-56.

Buchardt, B. 1978: Oxygene isotope palaeotemperatures from the Tertiary period in the North Sea area. Nature 275: 121-123.

Chene, R. J. du 1977: Étude palynologique du Miocène Superieur Andalou (Espagne). Revista Española de Micropal. IX: 97-114.

Cookson, I. C. and Eisenack, A. 1968: Microplankton from two samples from Gingin Brook No. 4 Borehole, Western Australia. Royal Soc. Western Australia Jour. 51: 110-122.

Cookson, I. C. \& Eisenack, A. 1974: Mikroplankton aus australischen mesozoischen und tertiären Sedimenten. Palaeontographica, Abt. B 148: 44-93.

Dale, B. 1976: Cyst formation, sedimentation and preservation: factors affecting dinoflagellate assemblages in Recent sediments from Trondheimsfjord, Norway. Rev. Palaeobot. Palynol. 22: 39-60.

Davey, :R. J.: and Williams,: G. L. 1966: The genus ,Hystrichosphaeridium and its allies. In: Davey, R. J., Downie, C., Sarjeant, W. A. S. and Williams, G. L.: Studies on Mesozoic and Cainozoic dinoflagellate cysts. Bull. Brit. Mus. (Nat. Hist.) Geol., Supp. 3: 1-248. 
Davey, R. J., Downie, C., Sarjeant, W. A. S. and Williams, G. L. 1969: Appendix to "Studies on Mesozoic and Cainozoic dinöflagellate cysts". Bull. Brit. Mus. (Nat. Hist.) Geol., Appendix to Supp. 3, 1-17.

Deflandre, G. and Cookson, I. C. 1955: Fossil microplankton from Australian Late Mesozoic and Tertiary sediments. Australian Jour. Marine and Freshwater Research 6: 242-313.

Downie, C., Hussain, M. A. \& Williams, G. L. 1971: Dinoflagellate cysts and acritarch association in the Palaeogene of Southeast England. Geoscience and Man 3: 29-35.

Drugg, W. S. 1970: Two new Neogene species of Tuberculodinium and one of Xenicodinium (Pyrrhophyta). Biol. Soc. Washington Proc. 83: 115-121.

Drugg, W. S. and Loeblich, A. R. jr. 1967: Some Eocene and Oligocene phytoplankton from the Gulf Coast, U.S.A. Tulane Studies Geology 5: 181-194.

Eaton, G. L. 1976: Dinoflagellate cysts from the Bracklesham Beds (Eocene) of the Isle of Wight, Southern England. Bull. Brit. Mus. (Nat. Hist) Geol. 26: 277-332.

Eisenack, A. 1954: Mikrofossilien aus Phosphoriten des samlandischen Unteroligozäns und über die Einheitlichkeit der Hystrichosphaerideen. Palaeontographica, Abt. A, 105: 49-95.

Eisenack, A. 1958: Mikroplankton aus dem norddeutschen Apt nebst einigen Bemerkungen über fossile Dinoflagellaten. N. Jb. Geol. Paläont., Abh. 106: 383-422.

Ersgaard, G., Fine, S., Fredericia, J., Holm, L., Larson, K. \& Nygaard, E. 1977: Rapport over undersøgelser af de miocane lag gennemboret ved Gram. Unpublished report. Geological Museum, University of Copenhagen. (In Danish).

Evitt, W. R: 1976: The Pyrodinium tabulation as a pattern of major importance in fossil dinoflagellates. Abstract, $D i$ noflagellate Conference, Oslo, 11-13. Aug., 1976.

Evitt, W. R., Lentin, J. K., Millioud, M. E., Stover, L. E. \& Williams, G. L. 1977: Dinoflagellate cyst terminology. Geol. Surv. Can. Paper 76-24: 1-11.

Gerlach, E. 1961: Mikrofossilien aus dem Oligozän und Miozän Nordwestdeutschlands, unter besonderer Berücksichtigung der Hystrichosphaerideen und Dinoflagellaten. N. Jb. Geol. Paläont., Abh. 112: 143-228.

Gocht, H. 1975: Neuuntersuchung von Eodinia pachytheca Eisenack 1936 (Dinoflagellata, Oberjura). $N . \overline{J b}$. Geol. Paläont., $A b h$. 148: 12-32.

Habib, D. 1972: Dinoflagellate stratigraphy Leg 11, Deep Sea Drilling Project. In: Hollister, C. D., Erwing, J. I. et al., Initial reports of the Deep Sea Drilling Project. XI: $367-425$.

Hansen, J. M. 1977: Dinoflagellate stratigraphy and echinoid distribution in Upper Maastrichtian and Danian deposits from Denmark. Bull. geol. Soc. Denmark 26: 1-26.

Harland, R. 1977: Recent and Late Quaternary (Flandrian and Devensian) dinoflagellate cysts from marine continental shelf sediments around the British Isles. Palaeontographica, Abt. B, 164: 87-126.

Harland, R. 1978: Quaternary and Neogene dinoflagellate cysts. In: B. Thusu (ed.): Distribution of biostratigraphically diagnostic dinoflagellate cysts and miospores from the Northwest European continental shelf and adjacent areas. Continental Shelf Inst. Publ. 100: 7-17.

Klumpp, B. 1953: Beitrag zur Kenntnis der Mikrofossilien des mittleren und oberen Eozän. Palaeontographica, Abt. A, 103: 337-406.

Koch, B. E., Friedrich, W. L., Christensen, E. F. and Friis, E. M. 1973: Den miocane brunkulsflora og dens geologiske miljø i Søby-Fasterholt området sydøst for Herning. Dansk geol. Foren. Arsskrift for 1972: 1-57.

Koch, B. E. 1975: Trak af brunkulsbrydningens historie i Danmark. Museerne i Viborg Amt. 5: 1-18.
Kristoffersen, F. N. 1972: Foraminiferzonering i det jyske Miocæen. Dansk geol. Foren., Arsskrift for 1971: 79-85.

Krutzsch, W. 1959: Mikropaläontologische (sporenpaläontologische) Untersuchungen in der Braunkohle des Geiseltales. Geologie 8, 21-22: 1-425.

Lentin, J. K. and Williams, G. L. 1976: A monograph of fossil peridinoid dinoflagellate cysts. Bedford Inst. Oceanography Rept. BI-R-75-16: 1-237.

Maier, D. 1959: Planktonuntersuchungen in tertiären und quartären marinen Sedimenten. N. Jb. Geol. Paläont., Abh. 107: 278-340.

Manum, S. B. 1976: Dinocrysts in Tertiary Norwegian-Greenland Sea sediments (Deep Sea Drilling Project Leg 38), with observations on palynomorphs and palynodebris in relation to environment. In Talwani, M., Udintsev, G. et al. 1976. Initial Reports of the Deep Sea Drilling Project 38: 897-919.

Morgenroth, P. 1966: Mikrofossilien und Konkretionen des nordwesteuropäischen Untereocäns. Palaeontographica, Abt. B, 119: 1-53.

Rasmussen, L. B. 1956: The marine Upper Miocene of South Jutland and its molluscan fauna. Danm. Geol. Unders. II rk., 81: 166 pp.

Rasmussen, L. B. 1961: De Miocane Formationer i Danmark. Danm. Geol. Unders. IV rk., 4 (5): 45 pp.

Rasmussen, L. B. 1966: Biostratigraphical studies on the marine younger Miocene of Denmark. Based on molluscan faunas. Geol. Surv. Denm., II series, 88: 358 pp.

Rasmussen, L. B. 1974: Some geological results from the first five exploration wells in the North Sea. Geol. Surv. Denm., III Series, 42: $46 \mathrm{pp}$.

Reid, P. C., 1974: Gonyaulacacean dinoflagellate cysts from the British Isles. Nova Hedwigia 25: 579-637.

Reid, P. C., 1977: Peridiniacean and Glenodiniacean dinoflagellate cysts from the British Isles. Nova Hedwigia 28

Rossignol, M. 1962: Analyse pollinique de sédiments marins Quaternaires en Israël. II. Sédiments Pleistocènes. Pollen et Spores 4: 121-148.

Sarjeant, W. A. S. 1970: The genus Spiniferites Mantell 1850 (Dinophyceae). Grana 10: 74-78.

Sorgenfrei, Th. 1940: Marint Nedre-Miocæn i Klintingehoved på Als. Danm. Geol. Unders. II rk. 65: $143 \mathrm{pp}$.

Sorgenfrei, Th. 1958: Molluscan assemblages from the marine Middle Miocene of South Jutland and their environments. Danm. Geol. Unders. II rk. 79 (I-II): 502 pp.

Stover, L. E. and Evitt, R. E. 1978: Analyses of Pre-Pleistocene organic-walled dinoflagellates. Stanford University Publications, Geological Science XV: 300 pp.

Talwani, M., Udintsev, G. et al. 1976: Initial Reports of the Deep Sea Drilling Project, Vol. 38, Washington (U. S. Government Printing Office), 1256 pp.

Wall, D. 1967: Fossil microplankton in deep-sea cores from the Caribbean Sea. Palaeontology 10: 95-123.

Wall, D. and Dale, B. 1969: The "hystrichosphaerid" resting spore of the dinoflagellate Pyrodinium bahamense Plate, 1906. J. Phycol. 5: 140-149.

Wall, D., Dale, B. and Harada, K. 1973: Descriptions of new fossil dinoflagellates from the Late Quaternary of the Black Sea. Micropaleontology 19: 18-31.

Wall, D., Dale, B., Lohmann, G. P. \& Smith, W. K. 1977: The environmental and climatic distribution of dinoflagellate cysts in modern marine sediments from regions in the North and South Atlantic Oceans and adjacent seas. Marine Micropalaeontology, 2: 121-200.

Van Geel, B. 1976: Fossil spores of Zygnemataceae in the ditches of a prehistoric settlement in Hoogkarspel (The Netherlands). Rev. Palaeobot. Palynol. 22: 337-344.

Van Geel, B. 1978: A palaeoecological study of Holocene peat bog sections in Germany and the Netherlands, based on the analysis of pollen, spores and macro- and microscopic 
remains of fungi, algae, cormophytes and animals. Rev. Paleobot. Palynol. 25: 1-120.

Van Geel, B. and Van der Hammen, T. 1978: Zygnematacea in Quaternary Colombian sediments. Rev. Palaeobot. Palynol. 25: 377-392.

Williams, D. B. 1971: The occurrence of dinoflagellates in marine sediments. In: Funnel, B. M. and Riedel, W. R. (eds): Micropalaeontology of Oceans, C.U.P. Cambridge. 231-243.
Williams, G. L. and Brideaux, W. W. 1975: Palynologic analysis of Upper Mesozoic and Cenozoic rocks of the Grand Banks, Atlantic continental margin. Geological Survey of Canada, Bull. 236: 162 pp.

Wilson, G. J. 1973: Palynology of the middle Pleistocene Te Piki bed, Cape Runaway, New Zealand. New Zealand Jour. Geology and Geophysics 16: 345-354. 